Mr Luka Grbović, pukovnik, dipl. inž.

Uprava za odbrambene tehnologije MO

Beograd

Slaviša Stoiljković, potpukovnik, dipl. inž.

Tehnički remontni zavod,

Kragujevac

\section{ANALIZA REZULTATA ODREĐIVANJA SADRŽAJA STABILIZATORA U PRIRODNO STARENIM BARUTIMA}

UDC: $662.3: 662.216 .1$

Rezime:

Praćenje sadržaja stabilizatora jedna je od savremenih i pouzdanih metoda koja se $u$ svetu, a i kod nas, primenjuje za kontrolu hemijske stabilnosti i prognoziranje veka upotrebljivosti baruta. Radi ocene hemijske stabilnosti baruta domaće proizvodnje u radu su analizirani rezultati određivanja sadržaja stabilizatora u prirodno starenim jednobaznim barutima tipa NC $i$ NCD i dvobaznim barutima tipa NGB i NGH. Pri tome su uporedno analizirani rezultati uzoraka iz kolekcija baruta iz Kragujevca (KB-1) i Zelenike (KB-2). Dobijeni rezultati ukazuju na znatno brži pad stabilnosti uzoraka baruta iz kolekcije KB-2, što se može objasniti značajnim uticajem klimatskih uslova. Osim toga, dobijeni rezultati potvrđuju uticaj mnogih faktora na hemijsku stabilnost baruta, kao što su: sastav, kvalitet sirovina, tehnološki postupak, oblik i dimenzije barutnog zrna i sl.

Ključne reči: barut, hemijska stabilnost, stabilizator, tečna hromatografija.

\title{
CONTENT OF STABILIZER DETERMINATION RESULTS ANALYSIS OF NATURALLY AGED GUN PROPELLANTS
}

Summary:

Monitoring of the stabilizer content is one of the modern and reliable methods in the world, and here also, which is used to control chemical stability and to predict the usage time of gun propellants. For the purpose of evaluation of gun propellants' chemical stability manufactured in our country, in this paper we analyzed results from the content of stabilizer determination in naturally aged single base, NC and NCD type, and double base, NGB and NGH type of gun propellants. At the same time we analyzed results from both collections of gun propellant samples, one from Kragujevac factory $(K B-1)$ and the other from Zelenika factory $(K B-2)$. Obtained results point that the stability decays faster for KB-2 collection samples, which can be explained due to climate factors. Beside this influence, obtained results prove the influence of many factors on chemical stability of gun propellants: used components, quality of the ingredients, procedures of manufacture, shape and dimensions of gun propellant grains, etc.

Key words: gun propellant, chemical stability, stabilizer, HPLC.

\section{Uvod}

Osnovna komponenta malodimnih baruta - nitroceluloza, po svojoj prirodi je hemijski nestabilna, i podložna termičkoj dekompoziciji (razgradnji) i na temperaturama okoline. Produkti dekompozicije nitroceluloze su azotni oksidi, koji autokata- liziraju dalju razgradnju i tako uzrokuju promenu fizičko-hemijskih osobina baruta. Da bi se usporila njena razgradnja, barutima se dodaju stabilizatori, supstance koje reaguju sa azotnim oksidima. Reakcije dekompozicije baruta i reakcije stabilizatora sa azotnim oksidima su egzotermne uzrokuju akumuliranje toplote i povećanje 
temperature u masi baruta, što u određenim kritičnim uslovima može dovesti i do samozapaljenja baruta.

Stabilnost baruta je rezultat uticaja brojnih parametara od kojih neki, još uvek, nisu dovoljno proučeni, pa je postizanje zadovoljavajuće stabilnosti u dužem periodu čuvanja i danas predmet mnogih istraživanja.

\section{Stabilnost i vek trajanja baruta}

Od kada je proizveden prvi barut na bazi nitroceluloze (pre više od 150 godina), prisutan je problem njegove stabilnosti i veka trajanja $[1,2]$. Pod stabilnošću baruta podrazumeva se zadržavanje njegovih početnih karakteristika na nivou koji garantuje bezbednu upotrebu i čuvanje bez rizika u uslovima skladištenja, a obuhvata hemijsku, balističku i mehaničku stabilnost.

Hemijska stabilnost baruta bavi se problemom termičke dekompozicije baruta. Produkti razgradnje nitroestera (azotni oksidi) autokataliziraju dalju razgradnju baruta. Budući da se radi o egzotermnim reakcijama, dolazi do akumuliranja toplote (barut je loš provodnik toplote) i povećanja temperature u masi baruta, što može prouzrokovati samozapaljenje. Da bi se usporila autokatalizirajuća razgradnja estera azotne kiseline, barutima se dodaju stabilizatori, centralit (CI) i difenilamin (DFA) - supstance koje akceptiraju produkte razgradnje (azotne okside). Autokataliza se odlaže zahvaljujući tome što $\mathrm{NO}_{2}$ reaguje oko 20000 puta brže sa CI i DFA nego sa osnovnim komponentama baruta (nitrocelulozom i nitroglicerinom) $[3,4]$.
Markrol (Marquerol) je utvrdio da je DFA odličan stabilizator nitroceluloznih baruta, ali samo u količinama do 5\% jer pri većoj količini DFA uzrokuje hidrolizu nitroceluloze [1]. U reakcijama DFA sa azotnim oksidima prvo nastaju mononitro derivati DFA (N-nitrozodifenilamin, 2-nitrodifenilamini, 4-nitrodifenilamin), koji su bazičnog karaktera i veoma dobri stabilizatori nitroceluloznih i dvobaznih baruta. Pod daljim uticajem azotnih oksida nastaju dinitro derivati DFA, a stabilizirajuće dejstvo DFA prestaje nastajanjem trinitrodifenilamina $[1,3,4]$.

Šreder (Schoeder) je utvrdio da je dietildifenilkarbamid - centralit I odličan stabilizator za dvobazne i trobazne barute. U prvoj fazi reakcije centralita sa azotnim oksidima nastaju mononitro derivati (2-nitrocentralit, 4-nitrocentralit, N-nitrozo-N-etilanilin) koji imaju stabilizirajuće delovanje (akceptiraju azotne okside). U kasnijim fazama nastaju dinitro i trinitro derivati koji nemaju stabilizirajućih svojstava [1].

\section{Metode za kontrolu hemijske stabilnosti i prognoziranje veka trajanja baruta}

Da bi se neka metoda mogla koristiti za ocenu hemijske stabilnosti baruta, trebalo bi da bude brza, jednostavna, pouzdana, reproduktivna i da omogućava predviđanje ponašanja baruta u toku dugogodišnjeg čuvanja municije u skladištima. Postoji veliki broj metoda koje se koriste za kontrolu hemijske stabilnosti baruta, odnosno za prognoziranje njegovog veka trajanja. U procesu skladištenja ubojnih sredstava, prema $\mathrm{SNO}$ 8069/91, kod nas se u tu svrhu koriste slede- 
će tri metode: metoda grejanja na $100^{\circ} \mathrm{C}$, metoda praćenja sadržaja stabilizatora i metoda merenja toplotne aktivnosti - mikrokalorimetrija [2].

\section{Metoda grejanja na $100^{\circ} \mathrm{C}$}

Kriterijum za ocenu hemijske stabilnosti baruta po metodi grejanja na $100^{\circ} \mathrm{C}$ je broj dana i sati od početka stavljanja uzorka baruta u aparat, da se greje na povišenoj temperaturi, do početka izdvajanja vidljivih azotnih oksida (gasovi žutosmeđe boje).

Metoda grejanja na $100^{\circ} \mathrm{C}$ je indikativna, naročito za NC barute. Barut koji zadovoljava po ovoj metodi hemijski je stabilan i obrnuto - barut koji ne zadovoljava po ovoj metodi ima narušenu hemijsku stabilnost, u manjoj ili većoj meri zavisno od rezultata. Zbog svoje jednostavnosti i dugogodišnjeg iskustva ona je pogodna za primenu kao indikativna metoda u kontroli hemijske stabilnosti baruta.

\section{Određivanje sadržaja stabilizatora}

$\mathrm{Na}$ temperaturi skladištenja reakcija utroška stabilizatora usled termičke dekompozicije baruta, do koncentracije $50 \%$ od početne, može se smatrati (aproksimirati) nepovratnom reakcijom prvog reda. U tom slučaju konstanta brzine reakcije $(k)$ je $[2,4]$ :

$k=\frac{1}{t_{s k}} \ln \frac{C_{0}}{C}$

gde je:

$t_{s k}$ - vreme skladištenja,

$C_{0}$ - početna koncentracija stabilizatora,

$C$ - koncentracija stabilizatora u nekom vremenu todvijanja reakcije.
Poznavanjem konstante brzine reakcije utroška stabilizatora može se, na osnovu izraza (1), prognozirati promena sadržaja stabilizatora sa vremenom, a time i vek trajanja baruta, zavisno od usvojenog kriterijuma kritičnog sadržaja stabilizatora. U svetu ti kriterijumi još uvek nisu jedinstveni i predmet su istraživanja. Ako se za kriterijum stabilnosti usvoji pad sadržaja stabilizatora na $50 \%$ od početne vrednosti, vek trajanja baruta je jednak poluvremenu reakcije utroška stabilizatora:

$\tau=\frac{\ln 2}{k}$

Dakle, vek trajanja baruta je vreme za koje koncentracija stabilizatora dostigne polovinu svoje početne vrednosti.

\section{Mikrokalorimetrija}

Ova metoda podrazumeva merenje brzine razvijanja toplote $u$ najkritičnijem delu uzorka (geometrijskom centru) za vreme termostatiranja na određenoj temperaturi $[2,3,4]$. Poznavanjem količine toplote koja se akumulira u jedinici vremena, pri dekompoziciji uzorka baruta; onih dimenzija koje odgovaraju realnim dimenzijama zrna, ili kalibru municije, može se odrediti:

- energija aktivacije procesa dekompozicije baruta;

- vreme do gubitka određene količine toplote u uslovima skladištenja, što može poslužiti kao mera balističke stabilnosti baruta; - veličina kritičnog prečnika na osnovu kojeg se može proceniti mogućnost samozapaljenja baruta. 
Mikrokalorimetrija je savremena metoda koja jedina prati direktni uzročnik samozapaljenja - brzinu oslobađanja toplote. U nekim zemljama je veoma usavršena (Švedska). Kod nas je uvedena pre 15 godina i još uvek je u fazi usavršavanja. Dobijeni rezultati, uglavnom, korespondiraju sa rezultatima dobijenim merenjem sadržaja stabilizatora. Unapređenje ove metode kod nas zahteva nabavku veoma skupe opreme, jer je postojeća skromnih mogućnosti.

\section{Opis istraživanja}

Izvršena je analiza rezultata ispitivanja hemijske stabilnosti baruta sprovedenih u TRZ Kragujevac određivanjem sadržaja stabilizatora metodom UV-VIS spektrofotometrije (spektrofotometar ,Perkin Elmer lambda 25") i tečne hromatografije - HPLC (tečni hromatograf „LDC - Milton Roy 3000“ sa UV detektorom).

Analizirani su rezultati sadržaja stabilizatora prirodno starenih baruta domaće proizvodnje, $\mathrm{i}$ to jednobaznih baruta tipa NC i NCD i dvobaznih baruta tipa NGB i NGH. Za svaki tip baruta analizirano je više vrsta, a unutar svake vrste analizirani su ukupno raspoloživi rezultati od svih kolekcioniranih serija baruta. Rezultati sadržaja stabilizatora grupisani su prema vremenu skladištenja (eksploatacije) baruta $t_{\text {sk }}$ - broj godina od proizvodnje do ispitivanja.

U okviru analize rezultata sadržaja stabilizatora po tipovima, vrstama i vremenu skladištenja, posebno su analizirani rezultati uzoraka baruta iz kolekcije Kragujevac (KB-1) i kolekcije Zelenika (KB-2). Pri tome su upoređivani, uglav- nom, rezultati istih serija baruta nakon jednakog vremena skladištenja, a u nekim slučajevima, usled nedostatka podataka, upoređivani su i rezultati različitih serija iste vrste baruta, dobijeni nakon jednakog perioda skladištenja $u$ dve različite klimatske zone (KB-1 i KB-2).

$\mathrm{Za}$ ocenu stabilnosti jedne vrste baruta, nakon konkretnog vremena eksploatacije, uzimana je srednja vrednost rezultata od najmanje pet serija nakon istog (konkretnog) vremena skladištenja, $\mathrm{s}$ tim da nisu uzimani u obzir rezultati koji odstupaju od srednje vrednosti više od $\pm 10 \%$.

$\mathrm{Na}$ osnovu srednje vrednosti rezultata sadržaja stabilizatora od više vrsta baruta, koji pripadaju jednom tipu baruta, izračunate su srednje vrednosti parametara hemijske stabilnosti baruta za svaki analizirani tip baruta.

Osnovni sastav analiziranih baruta, prema SNO za svaku vrstu, prikazan je u tabeli 1 [5].

Tabela 1

Sastav ispitivanih baruta

\begin{tabular}{|c|c|c|c|c|c|c|c|}
\hline $\begin{array}{c}\text { Tip i } \\
\text { vrsta } \\
\text { baruta }\end{array}$ & $\begin{array}{c}\% \\
\mathrm{NC}\end{array}$ & $\begin{array}{c}\% \mathrm{~N}_{2} \mathrm{u} \\
\mathrm{NC}\end{array}$ & $\begin{array}{c}\% \\
\text { NGL }\end{array}$ & $\begin{array}{c}\% \\
\text { DNT }\end{array}$ & $\begin{array}{c}\% \\
\text { DFA }\end{array}$ & $\begin{array}{c}\% \\
\text { CI }\end{array}$ & $\begin{array}{c}\% \\
\text { vlage }\end{array}$ \\
\hline 1 & 2 & 3 & 4 & 5 & 6 & 7 & 8 \\
\hline NC-A & 97,5 & 13,10 & & & 1,60 & & 1,30 \\
\hline NC-B & 96,8 & 13,10 & & & 1,50 & & 1,35 \\
\hline NC-C & 94,3 & 13,05 & & & 1,20 & 4,00 & 1,25 \\
\hline NC-D & 96,7 & 13,10 & & & 1,50 & & 1,35 \\
\hline NC-E & 97,4 & 13,10 & & & 1,60 & & 1,30 \\
\hline NC-F & 97,5 & 12,95 & & & 1,10 & & 1,30 \\
\hline NC-G & 96,8 & 13,25 & & & 1,40 & & 1,20 \\
\hline NC-H & 96,75 & 13,00 & & & 1,50 & & 1,35 \\
\hline NCD-A & 82,9 & 13,05 & & 9,75 & 1,30 & & 0,60 \\
\hline NCD-B & 82,6 & 13,05 & & 9,75 & 1,30 & & 0,60 \\
\hline NCD-C & 86,0 & 13,05 & & 9,75 & 1,30 & & 0,60 \\
\hline NGB-A & 57,5 & 12,75 & 40,50 & & & 1,70 & 0,50 \\
\hline NGB-B & 57,5 & 12,75 & 40,50 & & & 1,70 & 0,50 \\
\hline NGB-C & 58,0 & 12,15 & 40,00 & & & 1,70 & 0,30 \\
\hline NGB-D & 57,5 & 12,75 & 40,50 & & & 1,70 & 0,30 \\
\hline NGB-E & 58,0 & 12,15 & 40,00 & & & 1,70 & 0,30 \\
\hline NGH-A & 56,0 & 12,05 & 26,80 & 9,00 & & 3,00 & 0,70 \\
\hline NGH-B & 56,0 & 12,05 & 26,60 & 9,00 & & 3,00 & 0,70 \\
\hline
\end{tabular}




\section{Analiza rezultata}

\section{JEDNOBAZNI BARUTI}

\section{NC baruti}

Sumarni prosečni rezultati ispitivanja promene sadržaja stabilizatora četiri vrste NC baruta iz KB-1 i pet vrsta NC baruta iz KB-2 prikazani su u tabeli 2.

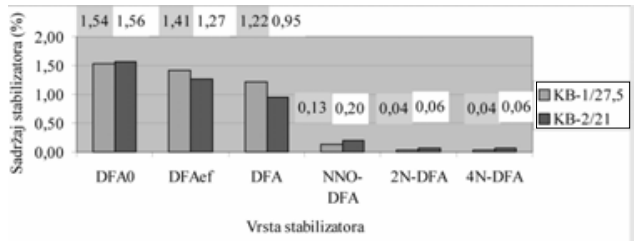

Sl. 1 - Prosečna promena sadržaja stabilizatora NC baruta nakon 27,5 godina u KB-1, odnosno 21 godinu и $\mathrm{KB}-2$

Tabela 2

Rezultati ispitivanja sadržaja stabilizatora NC baruta

\begin{tabular}{|c|c|c|c|c|c|c|c|c|c|c|c|c|c|c|c|c|}
\hline \multirow[b]{2}{*}{$\begin{array}{l}\dot{\Xi} \\
\dot{\Xi} \\
\check{\Delta}\end{array}$} & \multirow[b]{2}{*}{ 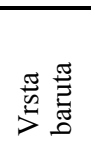 } & \multirow[b]{2}{*}{$\begin{array}{l}: \stackrel{\pi}{\vec{D}} \\
\dot{\infty} \\
\dot{\vec{\varphi}}\end{array}$} & \multirow[b]{2}{*}{$\mathrm{t}_{\mathrm{sk}}$} & \multirow[b]{2}{*}{$\begin{array}{c}\mathrm{C}_{0} \\
(\%)\end{array}$} & \multicolumn{4}{|c|}{ C, \% (HPLC) } & \multirow[b]{2}{*}{ 星 } & \multirow[b]{2}{*}{ 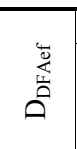 } & \multicolumn{2}{|c|}{ SD } & & \multirow[b]{2}{*}{$\tau$} & \multirow[b]{2}{*}{$\underline{\underline{v}}$} \\
\hline & & & & & DFA & $\begin{array}{l}\text { NNO- } \\
\text { DFA }\end{array}$ & $\begin{array}{l}2 \mathrm{~N}- \\
\text { DFA }\end{array}$ & $\begin{array}{l}\text { 4N- } \\
\text { DFA }\end{array}$ & & & 㭊 & $\begin{array}{l}\stackrel{4}{⿺} \\
\stackrel{4}{0}\end{array}$ & 㭊 & $\begin{array}{l}\frac{4}{4} \\
\underset{4}{4} \\
\frac{1}{0}\end{array}$ & & \\
\hline 1 & 2 & 3 & 4 & 5 & 6 & 7 & 8 & 9 & 10 & 11 & 12 & 13 & 14 & 15 & 16 & 17 \\
\hline 1. & NC-B & 6 & 25 & 1,48 & 1,16 & 0,09 & 0,03 & 0,04 & 21,54 & 10,68 & 0,02 & 0,09 & 0,01 & 0,06 & 72,2 & 1 \\
\hline 2. & NC-D & 9 & 25 & 1,46 & 1,17 & 0,10 & 0,02 & 0,03 & 19,73 & 9,30 & 0,05 & 0,10 & 0,03 & 0,07 & 80,2 & 1 \\
\hline 3. & $\mathrm{NC}-\mathrm{A}$ & 9 & 30 & 1,59 & 1,32 & 0,15 & 0,06 & 0,04 & 17,24 & 1,54 & 0,04 & 0,04 & 0,03 & 0,03 & 111,7 & 1 \\
\hline 4. & NC-E & 14 & 30 & 1,61 & 1,21 & 0,16 & 0,03 & 0,03 & 25,01 & 10,85 & 0,08 & 0,15 & 0,05 & 0,10 & 76,2 & 1 \\
\hline 5. & $\mathbf{A V}$ & 9,5 & $\mathbf{2 7 , 5}$ & 1,54 & 1,22 & $\mathbf{0 , 1 3}$ & 0,04 & 0,04 & 20,88 & 8,09 & $\mathbf{0 , 0 7}$ & 0,12 & 0,05 & 0,08 & 85,1 & 1 \\
\hline 6. & NC-D & 9 & 15 & 1,62 & 0,77 & 0,29 & 0,10 & 0,15 & 52,72 & 19,21 & 33 & 0,12 & 0,21 & 0,08 & 18,8 & 2 \\
\hline 7. & NC-F & 6 & 15 & 1,43 & 1,15 & 0,16 & 0,03 & 0,04 & 19,39 & 3,43 & 0,08 & 0,07 & 0,05 & 0,05 & 57,3 & 2 \\
\hline 8. & $\mathrm{NC}-\mathrm{H}$ & 10 & 15 & 1,55 & 1,28 & 0,15 & 0,04 & 0,02 & 17,29 & 3,72 & ,05 & 0,05 & 0,03 & 0,03 & 57,0 & 2 \\
\hline 9. & NC-A & 9 & 30 & 1,59 & 0,95 & 0,18 & 0,07 & 0,00 & 40,48 & 24,97 & 05 & 0,05 & 0,03 & 0,03 & 40,4 & 2 \\
\hline 10. & NC-E & 13 & 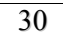 & 1,61 & 0,60 & 0,24 & 0,08 & 0,07 & 62,35 & 37,96 & 29 & 0,15 & 0,19 & 0,09 & 24,0 & 2 \\
\hline 11. & AV & 9,4 & 21,0 & 1,56 & 0,95 & $\mathbf{0 , 2 0}$ & 0,06 & 0,06 & 38,45 & 17,86 & 0,28 & 0,19 & 0,18 & 0,12 & 39,5 & 2 \\
\hline 12. & \multirow{2}{*}{ NC-A } & \multirow{2}{*}{9} & \multirow{4}{*}{30} & \multirow{2}{*}{1,59} & 1,32 & 0,15 & 0,06 & 0,04 & 17,24 & 1,54 & 0,04 & 0,04 & 0,03 & 0,03 & 111,7 & 1 \\
\hline 13. & & & & & 0,95 & 0,18 & 0,07 & 0,00 & 40,48 & 24,97 & 0,05 & 0,05 & 0,03 & 0,03 & 40,4 & 2 \\
\hline 14. & \multirow{2}{*}{ NC-E } & \multirow[b]{2}{*}{6} & & & 1,28 & 0,18 & 0,06 & 0,05 & 20,16 & 1,99 & 0,02 & 0,03 & 0,02 & 0,02 & 93,2 & 1 \\
\hline 15. & & & & 1,60 & 0,82 & 0,19 & 0,06 & 0,02 & 48,43 & 31,85 & 0,15 & 0,09 & 0,10 & 0,06 & 32,6 & 2 \\
\hline
\end{tabular}

NAPOMENA: $\mathrm{D}_{\mathrm{DFA}}=\left(\mathrm{C}_{0}-\mathrm{C}\right) \times 100 / \mathrm{C}_{0}, \mathrm{D}_{\mathrm{DFAef}}=\left(\mathrm{C}_{0}-\mathrm{C}_{\mathrm{ef}}\right) \times 100 / \mathrm{C}_{0}, \mathrm{SD}=$ standardna devijacija, $\delta=$ odstupanje od srednje vrednosti, $\mathrm{AV}=$ srednja vrednost.

Uočena je značajna razlika u stabilnosti između uzoraka NC baruta iz KB-1 i KB-2, čak i pri najopštijim poređenjima srednjih vrednosti rezultata određivanja sadržaja stabilizatora od uzoraka baruta različitih vrsta i različitih perioda skladištenja (slike 1 i 2 ). Baruti iz KB-2 pokazuju brži pad stabilnosti - smanjenje sadržaja DFA i povećanje sadržaja mono-nitro derivata DFA, što je posledica klimatskog faktora (veća prosečna temperatura, znatno veća vlažnost i uticaj slane atmosfere u zoni KB-2).

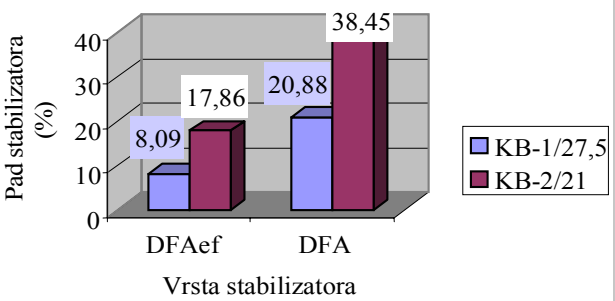

Sl. 2 - Pad sadržaja preostalog i efektivnog stabilizatora za NC barute nakon 27,5 godina $u$ $K B-1$, odnosno 21 godinu u $K B-2$

Osim toga, baruti iz KB-1 pokazuju manji pad efektivnog stabilizatora (zbir pre- 
ostalog DFA i nastalih mono-nitro derivata) u odnosu na barute iz KB-2, što se može objasniti činjenicom da u nepovoljnim uslovima, kakvi su u KB-2, nastaje veća količina azotnih oksida, proces dekompozicije NC se samoubrzava, stabilizator se brže troši, pored mononitro derivata DFA nastaju dinitro i trinitro derivati DFA, a menja se i model reakcije utroška stabilizatora (tako se red reakcije pomera od prvog ka nultom redu).

Nepovoljan uticaj uslova u KB-2 na hemijsku stabilnost baruta potvrđuju rezultati hemijske stabilnosti od svih vrsta $\mathrm{NC}$ baruta, a posebno egzaktno od 9 istih serija baruta NC-A i 6 istih serija baruta NC-E nakon jednakog vremena skladištenja (30 godina) u KB-1 i KB-2, koji su prikazani u tabeli 2 i na slikama 3 i 4 . Osim toga, analizom ovih rezultata uočena je bolja stabilnost baruta NC-A u odnosu na barut NC-E, po rezultatima iz obe kolekcije. S obzirom na to da su baruti NC-A i NC-E praktično istog hemijskog sastava, ova pojava se jedino može objasniti njihovim različitim oblicima (barut NC-A ima oblik jednokanalne cilindrične cevčice, a barut NC-E je cilindričnog oblika sa sedam kanala). Iako ovi baruti imaju gotovo identičan odnos površine $\mathrm{i}$ mase (NC-A $=0,68 ; \mathrm{NC}-\mathrm{E}=0,70 \mathrm{~mm}^{2} / \mathrm{mg}$ ), a s obzirom na dobru stabilnost drugih baruta koji, takođe, imaju oblik jednokanalne cevčice (NGH-A i NGH-B), može se

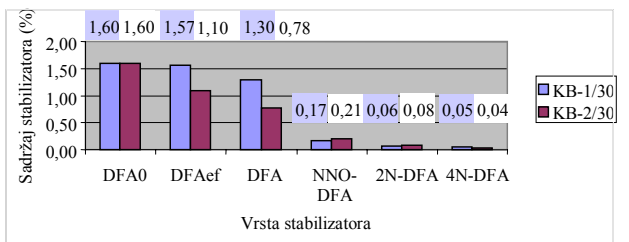

Sl. 3 - Zavisnost promene sadržaja stabilizatora baruta NC-A i NC-E od uslova čuvanja

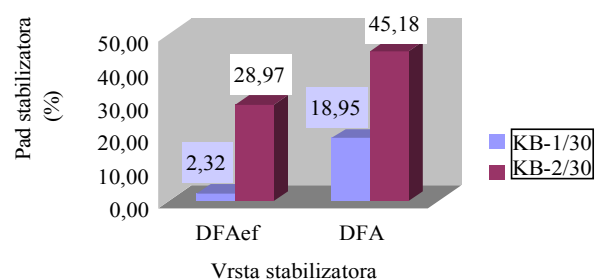

Sl. 4 -Zavisnost pada preostalog $i$ efektivnog stabilizatora od uslova čuvanja za barute NC-A $i$ $N C-E$

zaključiti da je jednokanalna cevčica povoljnija za hemijsku stabilnost baruta, jer omogućava bržu izmenu nastale toplote $\mathrm{u}$ barutu sa okolinom, čime se usporava i odlaže autokatalitički proces hemijske degradacije baruta.

Pojedine serije NC baruta iz KB-2 pokazuju drastičan pad stabilnosti i znatno odstupaju od prosečnih rezultata. Podaci su prikazani u tabeli 3 .

Analizom rezultata hemijske stabilnosti baruta, iz tabele 3, uočeno je da pojedine serije, praktično od svih vrsta NC baruta, nakon određenog perioda skladištenja, pre svega u uslovima KB-2, pokazuju nagli pad hemijske stabilnosti. Za većinu baruta to je period od 15 do 20 godina, a za izrazito stabilne barute (poput NC-A) to je period od 25 do 30 godina. Nakon kritičnog perioda, kod određenih serija NC baruta dolazi do naglog ubrzanja reakcije stabilizatora sa azotnim oksidima i promene mehanizma odvijanja reakcije od prvog ka nultom redu. Ovu tvrdnju potkrepljuju sledeći primeri:

- NC-A: velika je razlika u stabilnosti za serije koje su ispitane nakon istog perioda skladištenja od 30 godina; razlika je samo u godini proizvodnje. Serije iz 1970. godine (9 serija) stabilnije su od serija koje su proizve- 
Tabela 3

Rezultati ispitivanja sadržaja stabilizatora NC baruta iz KB-2 karakteristični primeri

\begin{tabular}{|c|c|c|c|c|c|c|c|c|c|c|c|c|c|c|c|c|}
\hline \multirow[b]{2}{*}{$\begin{array}{l}\dot{\Delta} \\
\dot{0} \\
\approx \\
\simeq\end{array}$} & \multirow[b]{2}{*}{ 焉 } & \multirow[b]{2}{*}{$\begin{array}{l}: \frac{\pi}{\vec{D}} \\
\dot{D} \\
\dot{m} \\
.0\end{array}$} & \multirow[b]{2}{*}{$t_{\mathrm{sk}}$} & \multirow[b]{2}{*}{$\begin{array}{c}\mathrm{C}_{0} \\
(\%)\end{array}$} & \multicolumn{4}{|c|}{ C, \% (HPLC) } & \multirow[b]{2}{*}{ 鹿 } & \multirow[b]{2}{*}{ 㟋 } & \multicolumn{2}{|c|}{ SD } & \multicolumn{2}{|c|}{$\delta$} & \multirow[b]{2}{*}{$\tau$} & \multirow[b]{2}{*}{ 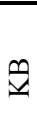 } \\
\hline & & & & & DFA & $\begin{array}{l}\text { NNO- } \\
\text { DFA }\end{array}$ & $\begin{array}{l}\text { 2N- } \\
\text { DFA }\end{array}$ & $\begin{array}{l}\text { 4N- } \\
\text { DFA }\end{array}$ & & & 㭊 & $\begin{array}{l}\sum_{0}^{4} \\
\text { 殅 }\end{array}$ & $\begin{array}{l}\overleftrightarrow{4} \\
\text { 㟔 }\end{array}$ & 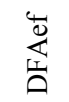 & & \\
\hline 1 & 2 & 3 & 4 & 5 & 6 & 7 & 8 & 9 & 10 & 11 & 12 & 13 & 14 & 15 & 16 & 17 \\
\hline 1. & \multirow{5}{*}{ NC-A } & 9 & 30 & \multirow{5}{*}{1,59} & 0,95 & 0,18 & 0,07 & 0,00 & 40,48 & 24,97 & 0,05 & 0,05 & 0,03 & 0,03 & 40,35 & 2 \\
\hline 2. & & 5 & 30 & & 0,52 & 0,28 & 0,08 & 0,10 & 67,14 & 37,51 & 0,16 & 0,13 & 0,10 & 0,08 & 19,25 & 2 \\
\hline 3. & & \multirow{3}{*}{3} & 30 & & 0,15 & 0,33 & 0,14 & 0,13 & 90,30 & 52,76 & 0,04 & 0,06 & 0,02 & 0,04 & 8,90 & \multirow{3}{*}{2} \\
\hline 4. & & & 31 & & 0,13 & 0,30 & 0,14 & 0,16 & 92,01 & 54,37 & 0,05 & 0,07 & 0,03 & 0,04 & & \\
\hline 5. & & & 32 & & 0,02 & 0,36 & 0,16 & 0,21 & 98,72 & 52,57 & 0,03 & 0,07 & 0,02 & 0,04 & & \\
\hline 6. & \multirow{4}{*}{ NC-B } & \multirow{2}{*}{3} & \multirow{2}{*}{$15-16$} & \multirow{2}{*}{1,54} & 1,17 & 0,12 & 0,04 & 0,04 & 24,41 & 11,03 & 0,06 & 0,09 & 0,04 & 0,06 & 40,32 & 1 \\
\hline 7. & & & & & 0,02 & 0,36 & 0,13 & 0,13 & 98,49 & 57,50 & 0,02 & 0,15 & 0,01 & 0,10 & 2,93 & 2 \\
\hline 8. & & \multirow{2}{*}{1} & 15 & \multirow{2}{*}{1,64} & 1,24 & 0,16 & 0,04 & 0,08 & 24,39 & 7,32 & & & & & 39,67 & 2 \\
\hline 9. & & & 18 & & 0,00 & 0,03 & 0,11 & 0,06 & 100,0 & 87,80 & & & & & - & 2 \\
\hline 10. & \multirow{2}{*}{ NC-D } & \multirow{2}{*}{3} & \multirow{2}{*}{15} & & 1,12 & 0,18 & 0,04 & 0,03 & 23,22 & 5,60 & 0,11 & 0,05 & 0,07 & 0,03 & 41,73 & 1 \\
\hline 11. & & & & 1,45 & 0,36 & 0,30 & 0,10 & 0,12 & 76,22 & 40,14 & 0,34 & 0,47 & 0,22 & 0,31 & 10,37 & 2 \\
\hline 12. & NC_F & 4 & 15 & & 1,20 & 0,16 & 0,03 & 0,03 & 14,85 & $-0,95$ & 0,03 & 0,04 & 0,02 & 0,02 & 70,42 & 2 \\
\hline 13. & $-\mathrm{F}$ & 4 & 19 & 1,41 & 0,00 & 0,17 & 0,17 & 0,19 & 100,0 & 62,41 & 0,00 & 0,09 & - & 0,06 & - & 2 \\
\hline 14. & $-G$ & 3 & 10 & 1,09 & 0,38 & 0,61 & 0,10 & 0,21 & 65,46 & 19,25 & 0,23 & 0,17 & 0,15 & 0,11 & 6,99 & 2 \\
\hline 15. & & & 17 & & 0,36 & 0,31 & 0,13 & 0,17 & 77,98 & 43,16 & 0,09 & 0,05 & 0,06 & 0,03 & 7,82 & 2 \\
\hline 16. & $\mathrm{NC}$ & 1 & 18 & 164 & 0,21 & 0,40 & 0,12 & 0,17 & 87,30 & 45,31 & 0,09 & 0,07 & 0,06 & 0,05 & 5,70 & 2 \\
\hline 17. & $-H$ & 4 & 19 & 1,04 & 0,18 & 0,34 & 0,13 & 0,13 & 89,01 & 52,53 & 0,02 & 0,04 & 0,01 & 0,03 & 5,33 & 2 \\
\hline 18. & & & 21 & & 0,09 & 0,43 & 0,13 & 0,17 & 94,53 & 50,26 & 0,03 & 0,05 & 0,02 & 0,04 & 4,04 & 2 \\
\hline 19. & NC-B & 4 & 15 & 1,60 & 0,11 & 0,29 & 0,18 & 0,29 & 93,47 & 45,87 & 0,11 & 0,57 & 0,07 & 0,37 & 3,71 & 2 \\
\hline 20. & NC-D & 6 & 20 & 1,60 & 0,13 & 0,41 & 0,15 & 0,20 & 91,76 & 43,98 & 0,04 & 0,06 & 0,03 & 0,04 & 5,53 & 2 \\
\hline 21. & NC-H & 7 & 19,3 & 1,60 & 0,19 & 0,34 & 0,14 & 0,16 & 88,32 & 48,05 & 0,05 & 0,13 & 0,03 & 0,08 & 6,19 & 2 \\
\hline 22. & NC-H & 7 & 21,3 & 1,60 & 0,08 & 0,41 & 0,14 & 0,17 & 94,86 & 50,06 & 0,04 & 0,04 & 0,02 & 0,03 & 4,89 & 2 \\
\hline 23. & AV & 6,0 & 19,0 & 1,60 & 0,13 & 0,36 & 0,15 & 0,21 & 92,10 & 46,90 & 0,05 & 0,04 & $\mathbf{0 , 0 3}$ & $\mathbf{0 , 0 3}$ & 5,08 & 2 \\
\hline 24. & & 12 & 15 & 1,24 & 0,95 & 0,14 & 0,01 & 0,02 & 22,99 & 9,84 & 0,14 & 0,12 & 0,09 & 0,08 & 48,78 & 2 \\
\hline 25. & & 6 & 20 & 1,20 & 0,05 & 0,34 & 0,09 & 0,16 & 96,23 & 46,85 & 0,07 & 0,16 & 0,04 & 0,11 & 4,69 & 2 \\
\hline 26. & NC-C & 5 & 15 & 4,36 & 3,59 & & & & 17,37 & & 0,24 & & 0,16 & & & 2 \\
\hline 27. & & 5 & 20 & 3,50 & 2,88 & & & & 17,53 & & 0,18 & & 0,12 & & & 2 \\
\hline 28. & & 6 & 26 & 3,31 & 2,55 & & & & 22,53 & & ${ }^{*} 0,20$ & & ${ }^{*} 0,13$ & & & 2 \\
\hline
\end{tabular}

NAPOMENA: rezultati od uzoraka iz KB-1 su dati radi poređenja, * - podaci se odnose na CI

dene 1972. godine (pet serija), odnosno znatno stabilnije od serija proizvedenih 1973. godine (tri serije), koje su najnestabilnije. To se može objasniti uticajem tehnološkog postupka i kvaliteta sirovina na hemijsku stabilnost baruta (logično je da su serije iz iste godine proizvedene po približno istom tehnološkom postupku i od sirovina istog kvaliteta). Primetan je veliki pad stabilnosti tri serije iz 1973. godine u toku sledeće dve godine skladištenja;
- NC-B: hemijska stabilnost serija MBL 8873, 8981 i 8985 nakon 15 do 16 godina skladištenja u KB-2 znatno je niža od prosečnih rezultata za NC barute iz KB-2, a drastično niža od rezultata istih serija nakon istog perioda skladištenja $u$ KB-1. Uočeno je da više uzoraka serija baruta NC-B nakon 15 godina čuvanja u KB-2 pokazuju nagli pad hemijske stabilnosti. To najbolje ilustruju rezultati hemijske stabilnosti serije MBL 8768 nakon 15 i 18 godina skladištenja; 
- NC-D: hemijska stabilnost serija MBL 89150, 89154 i 89157 nakon 15 godina skladištenja u KB-2 znatno je niža od prosečnih rezultata za NC barute iz KB-2, a drastično niža od rezultata tih serija nakon istog perioda skladištenja u KB-1;

- NC-F: hemijska stabilnost serija MBL 8613, 8614 i 8615 nakon 15 godina skladištenja u KB-2 je u nivou prosečnih rezultata za NC barute iz KB-2, a nakon 19 godina sledi drastičan pad hemijske stabilnosti istih serija;

- NC-G: hemijska stabilnost serija MBL 9407, 9511 i 9712 nakon prosečno 10 godina skladištenja u KB-1 znatno je niža od prosečnih rezultata za NC barute iz KB1. Praktično, to je jedinstven primer da NC barut nakon desetak godina čuvanja u KB-1 pokaže veliki pad hemijske stabilnosti, a objašnjava se hemijskim sastavom baruta. Naime, barut NC-G sadrži so kalijumsulfat (kalijumnitrat) [5], koja je izrazito higroskopna, a to u krajnjem veoma ubrzava proces degradacije baruta;

- NC-H: hemijska stabilnost 10 serija (proizvedenih 1985, 1987 i 1988) nakon 15 godina skladištenja u KB-2 je u nivou prosečnih rezultata za NC barute iz KB-2. Međutim, hemijska stabilnost drugih 6 serija (proizvedenih, uglavnom, 1984) nakon prosečno 19,3 godina skladištenja u KB-2 znatno je niža od prosečnih rezultata za NC barute iz KB-2, a pad stabilnosti tih 6 serija baruta $u$ istim uslovima nakon narednih dve godine veoma je ubrzan. Osim toga, drastičan pad hemijske stabilnosti uočen je kod četiri serije (proizvedene 1984) već nakon 17 godina skladištenja, a ubrzano opada tokom svake sledeće godine. Na osnovu iznetog očito je da barut $\mathrm{NC}-\mathrm{H}$ pokazuje manju stabilnost od baruta NC-A, iako se radi o barutima sličnog sastava i istog oblika barutnog zrna [5]. Baruti u obliku jednokanalne cevčice izrazito su stabilni. Uzrok manje stabilnosti pojedinih serija baruta NC-H verovatno je u tehnologiji i kvalitetu sirovina, što potvrđuje činjenica da su baruti proizvedeni 1984. godine pokazali prosečno znatno manju stabilnost od ostalih baruta ove vrste;

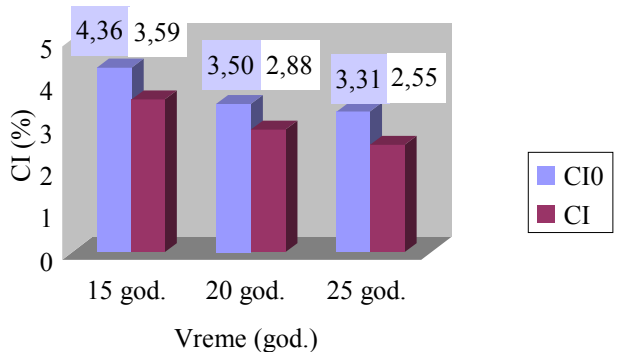

Sl. 5 - Utrošak CI sa vremenom u barutu NC-C

- NC-C: u okviru NC baruta posebno su specifični oni koji u svom sastavu pored DFA u svojstvu stabilizatora imaju i CI u svojstvu balističkog modifikatora (površinska obrada - poliranje) [1]. Tipičan predstavnik ovih baruta je NC-C [5]. Hemijska stabilnost 12 serija nakon 15 godina skladištenja u KB-2 je u nivou prosečnih rezultata za NC barute iz KB2. Nakon 20 godina čuvanja u KB-2 uzorci pokazuju pad stabilnosti, po HPLC metodi, ali po metodi grejanja na $100^{\circ} \mathrm{C}$ ovi baruti su izrazito stabilni, čak i onda kada se DFA potpuno potroši. To se objašnjava prisustvom CI (makar i na površini barutne mase), koji neminovno preuzima ulogu stabilizatora. U prilog ovom zaključku ide činjenica da se koncentracija CI smanjuje tokom vremena (slike 5 i 6). I ovde je uočeno da baruti istog godišta pokazuju približno istu sta- 


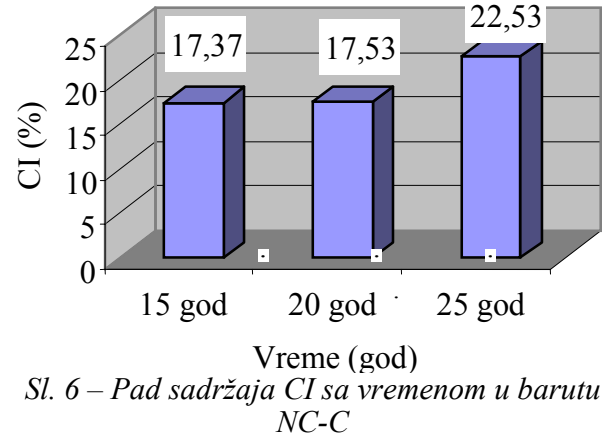

bilnost koja se znatno razlikuje od baruta drugog godišta nakon istog perioda skladištenja od 15 godina $u$ istim uslovima, što potvrđuje zaključak da tehnološki postupak i kvalitet sirovina bitno utiču na hemijsku stabilnost baruta.

\section{NCD baruti}

Sumarni prosečni rezultati ispitivanja promene sadržaja stabilizatora dve vrste NCD baruta iz KB-1 i tri vrste NCD baruta iz KB-2 prikazani su u tabeli 4.

Slično NC barutima, i NCD baruti iz KB-2 pokazuju manju stabilnosti u odnosu na barute iz KB-1, što je posledica uticaja klimatskog faktora.
Na slici 7 dato je poređenje pada stabilizatora NC i NCD baruta. Oba baruta $u$ KB-1 imaju približno istu stabilnost, ali u nepovoljnijim uslovima ( KB-2) NCD baruti su stabilniji i pokazuju znatno manje oscilacije u hemijskoj stabilnosti od NC baruta. Ovaj fenomen može se objasniti povoljnijim sastavom NCD baruta u odnosu na NC barute. Naime, NCD baruti imaju za 10 do 14\% manji sadržaj NC u barutnoj masi, a $\mathrm{NC}$ je glavni generator nestabilnosti baruta. Na račun NC, NCD baruti sadrže oko $10 \%$ DNT-a, koji je stabilno hemijsko jedinjenje. Osim toga, DNT vrši i delimičnu želatinizaciju molekula NC koja na taj način postaje stabilnija. Takođe, NCD baruti imaju manji početni sadržaj vlage i manje su higroskopni od NC baruta $[1,5]$.

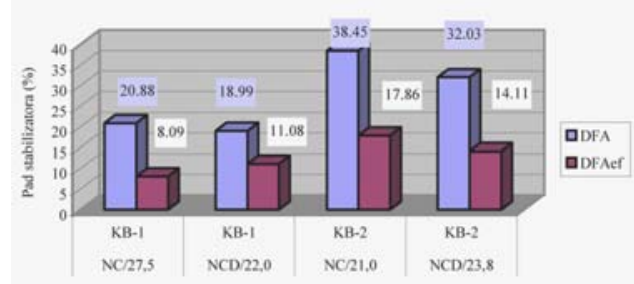

Sl. 7 - Poređenje pada stabilizatora za NC i NCD barute

Tabela 4

Rezultati ispitivanja sadržaja stabilizatora NCD baruta

\begin{tabular}{|c|c|c|c|c|c|c|c|c|c|c|c|c|c|c|c|c|}
\hline \multirow[b]{2}{*}{$\begin{array}{l}\vec{\vdots} \\
\overrightarrow{0} \\
\ddot{\Delta}\end{array}$} & \multirow[b]{2}{*}{ 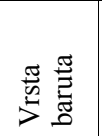 } & \multirow[b]{2}{*}{$\begin{array}{l}: \stackrel{\sigma}{\vec{\Xi}} \\
0 \\
\dot{0} \\
\dot{0}\end{array}$} & \multirow[b]{2}{*}{$t_{\mathrm{sk}}$} & \multirow[b]{2}{*}{$\begin{array}{c}\mathrm{C}_{0} \\
(\%)\end{array}$} & \multicolumn{4}{|c|}{$\mathrm{C}, \%$ (HPLC) } & \multirow[b]{2}{*}{ 死 } & \multirow[b]{2}{*}{ 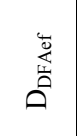 } & \multicolumn{2}{|c|}{ SD } & \multicolumn{2}{|c|}{$\delta$} & \multirow[b]{2}{*}{$\tau$} & \multirow[b]{2}{*}{$\underline{v}$} \\
\hline & & & & & DFA & $\begin{array}{l}\text { NNO- } \\
\text { DFA }\end{array}$ & $\begin{array}{l}\text { 2N- } \\
\text { DFA }\end{array}$ & $\begin{array}{l}\text { 4N- } \\
\text { DFA }\end{array}$ & & & $\underset{⿱ 亠 䒑}{\mathbb{a}}$ & 岕 & 㭊 & $\begin{array}{l}\stackrel{4}{0} \\
\underset{4}{4}\end{array}$ & & \\
\hline 1 & 2 & 3 & 4 & 5 & 6 & 7 & 8 & 9 & 10 & 11 & 12 & 13 & 14 & 15 & 16 & 17 \\
\hline 1. & NCD-A & 5 & 20 & 1,41 & 1,14 & 0,07 & 0,01 & 0,04 & 19,21 & 12,50 & 0,02 & 0,06 & 0,02 & 0,04 & 66,58 & 1 \\
\hline 2. & NCD-A & 5 & 26 & 1,42 & 1,14 & 0,12 & 0,02 & 0,00 & 19,32 & 9,15 & 0,04 & 0,04 & 0,03 & 0,03 & 89,01 & 1 \\
\hline 3. & NCD-B & 7 & 20 & 1,42 & 1,15 & 0,06 & 0,02 & 0,02 & 18,45 & 11,60 & 0,04 & 0,07 & 0,02 & 0,04 & 80,57 & 1 \\
\hline 4. & AV & 5,7 & 22,0 & 1,42 & 1,14 & \begin{tabular}{|c|}
0,08 \\
\end{tabular} & $\mathbf{0 , 0 2}$ & $\mathbf{0 , 0 2}$ & 18,99 & 11,08 & $\mathbf{0 , 0 1}$ & $\mathbf{0 , 0 3}$ & $\mathbf{0 , 0 0}$ & $\mathbf{0 , 0 2}$ & 78,72 & 1 \\
\hline 5. & NCD-A & 7 & 25 & 1,40 & 1,03 & 0,09 & 0,08 & 0,03 & 25,89 & 11,57 & 0,05 & 0,06 & 0,03 & 0,04 & 59,66 & 2 \\
\hline 6. & NCD-B & 5 & 20 & 1,38 & 0,99 & 0,10 & 0,07 & 0,03 & 27,87 & 13,17 & 0,05 & 0,06 & 0,03 & 0,04 & 44,09 & 2 \\
\hline 7. & NCD-B & 8 & 25 & 1,44 & 0,77 & 0,17 & 0,12 & 0,05 & 46,19 & 22,92 & 0,25 & 0,15 & 0,16 & 0,10 & 33,85 & 2 \\
\hline 8. & NCD-C & 10 & 25 & 1,43 & 1,02 & 0,14 & 0,09 & 0,05 & 28,17 & 8,77 & 0,25 & 0,14 & 0,16 & 0,09 & 79,13 & 2 \\
\hline 9. & AV & 7,5 & 23,8 & 1,41 & 0,95 & 0,13 & 0,09 & 0,04 & 32,03 & 14,11 & 0,12 & 0,08 & 0,08 & 0,05 & 53,43 & 2 \\
\hline
\end{tabular}




\section{DVOBAZNI BARUTI}

\section{$N G B$ baruti}

Sumarni prosečni rezultati hemijske stabilnosti pet vrsta NGB baruta prikazani su u tabeli 5. Većina rezultata odnosi se na uzorke baruta iz KB-2, izuzev baruta NGB-B za koji postoje rezultati od uzoraka iz KB-1 i KB-2. Rezultati baruta NGB-A odnose se na uzorke baruta delaborisane iz UbS, koja su čuvana u zoni $\mathrm{KB}-2$, pa su i ovi rezultati tretirani kao da su od uzoraka baruta iz KB-2.

Dvobazni barut NGB-B (slično jednobaznim barutima NC i NCD) pokazuje manju stabilnost u KB-2 u odnosu na KB-1.
U tabeli 6 i na slikama 8 i 9 prikazani su zbirni rezultati promene sadržaja stabilizatora kod NGB baruta iz KB-2, grupisani prema vremenu ispitivanja $\mathrm{i}$ metodama. Uočeno je da se po UV-VIS metodi dobijaju manje vrednosti sadržaja CI, veći pad stabilizatora i kraći vek trajanja NGB baruta nego po HPLC metodi.

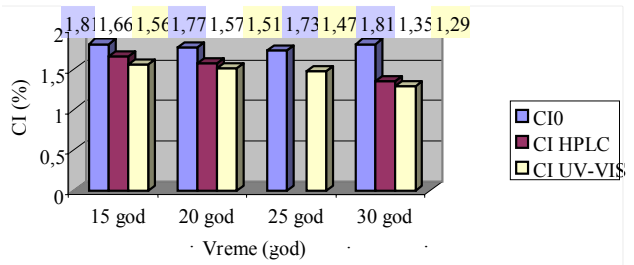

Sl. 8 - Zavisnost sadržaja stabilizatora u NGB barutima iz KB-2 sa vremenom

Tabela 5

Rezultati ispitivanja sadržaja stabilizatora NGB baruta

\begin{tabular}{|c|c|c|c|c|c|c|c|c|c|c|c|c|}
\hline \multirow[b]{2}{*}{$\begin{array}{l}\dot{0} \\
\dot{0} \\
\ddot{0} \\
\ddot{2}\end{array}$} & \multirow[b]{2}{*}{$\begin{array}{l}\text { Vrsta } \\
\text { baruta }\end{array}$} & \multirow[b]{2}{*}{ 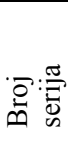 } & \multirow[b]{2}{*}{$\mathrm{t}_{\mathrm{sk}}$} & \multirow[b]{2}{*}{$\begin{array}{c}\mathrm{C}_{0} \\
(\%)\end{array}$} & \multicolumn{2}{|c|}{$\mathrm{C}_{\mathrm{CI}}, \%$} & \multicolumn{2}{|c|}{$\mathrm{D}_{\mathrm{CI}}, \%$} & \multirow[b]{2}{*}{$\mathrm{SD}_{\mathrm{CI}}$} & \multirow[b]{2}{*}{$\delta_{\mathrm{CI}}$} & \multirow[b]{2}{*}{$\tau$} & \multirow{2}{*}{ 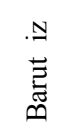 } \\
\hline & & & & & UV-VIS & HPLC & $\begin{array}{l}\text { UV- } \\
\text { VIS }\end{array}$ & HPLC & & & & \\
\hline 1 & 2 & 3 & 4 & 5 & 6 & 7 & 8 & 9 & 10 & 11 & 12 & 13 \\
\hline 1. & \multirow{2}{*}{ NGB-B } & \multirow{2}{*}{4} & \multirow{2}{*}{25} & \multirow{2}{*}{1,78} & 1,58 & & 11,19 & & 0,14 & 0,09 & 186,6 & KB-1 \\
\hline 2. & & & & & 1,48 & & 16,67 & & 0,07 & 0,04 & 100,4 & KB-2 \\
\hline 3. & NGB-A & 8 & 22,8 & 1,77 & 1,46 & & 17,54 & & 0,09 & 0,06 & 86,0 & UbS \\
\hline 4. & \multirow{2}{*}{ NGB-B } & 4 & 25 & 1,78 & 1,48 & & 16,67 & & 0,07 & 0,04 & 100,4 & \multirow{10}{*}{ KB-2 } \\
\hline 5. & & 4 & 30 & 1,79 & 1,29 & & 27,82 & & 0,06 & 0,04 & 65,3 & \\
\hline 6. & \multirow{3}{*}{ NGB-C } & 3 & 15 & 1,84 & 1,56 & & 14,71 & & 0,12 & 0,08 & 80,7 & \\
\hline 7. & & 5 & 20 & 1,79 & 1,49 & & 16,44 & & 0,08 & 0,05 & 80,1 & \\
\hline 8. & & 4 & 25 & 1,70 & 1,46 & & 14,12 & & 0,08 & 0,05 & 120,9 & \\
\hline 9. & NGB-D & 4 & 30 & 1,82 & 1,29 & & 29,26 & & 0,06 & 0,04 & 60,9 & \\
\hline 10. & \multirow{3}{*}{ NGB-E } & 9 & 15 & 1,77 & 1,55 & & 12,57 & & 0,12 & 0,08 & 118,9 & \\
\hline 11. & & 14 & 20 & 1,74 & 1,52 & & 12,26 & & 0,09 & 0,06 & 119,5 & \\
\hline 12. & & 6 & 25 & 1,70 & 1,46 & & 14,40 & & 0,05 & 0,03 & 113,3 & \\
\hline 13. & AV & 6,1 & 22,8 & 1,77 & 1,46 & & $\mathbf{1 7 , 5 8}$ & & 0,09 & 0,06 & 91,7 & \\
\hline 14. & NGB-A & 8 & 22,8 & 1,77 & & 1,45 & & 18,54 & 0,08 & 0,06 & 80,1 & UbS \\
\hline 15. & NGB-B & 3 & 30 & 1,80 & & 1,34 & & 25,88 & 0,05 & 0,03 & 69,9 & \multirow{9}{*}{ KB-2 } \\
\hline 16. & \multirow{3}{*}{ NGB-C } & 3 & 15 & 1,84 & & 1,67 & & 8,96 & 0,07 & 0,05 & 154,3 & \\
\hline 17. & & 5 & 20 & 1,79 & & 1,60 & & 10,59 & 0,07 & 0,04 & 130,3 & \\
\hline 18. & & 3 & 25 & 1,72 & & 1,56 & & 9,68 & 0,08 & 0,05 & 179,2 & \\
\hline 19. & NGB-D & 4 & 30 & 1,82 & & 1,36 & & 25,27 & 0,02 & 0,02 & 71,7 & \\
\hline 20. & \multirow{3}{*}{ NGB-E } & 9 & 15 & 1,77 & & 1,64 & & 7,07 & 0,07 & 0,04 & 221,6 & \\
\hline 21. & & 14 & 20 & 1,74 & & 1,53 & & 11,62 & 0,06 & 0,04 & 125,3 & \\
\hline 22. & & 6 & 25 & 1,70 & & 1,55 & & 9,20 & 0,06 & 0,04 & 191,2 & \\
\hline 23. & AV & 6,1 & 22,5 & 1,77 & & 1,52 & & 14,09 & 0,12 & 0,08 & 135,9 & \\
\hline
\end{tabular}


Tabela 6 Zbirni rezultati ispitivanja sadržaja stabilizatora NGB baruta, grupisani po godinama starosti

\begin{tabular}{|c|c|c|c|c|c|c|}
\hline \multirow{2}{*}{$t_{\mathrm{E}}$} & \multicolumn{3}{|c|}{ UV-VIS } & \multicolumn{3}{c|}{ HPLC } \\
\cline { 2 - 7 } & $\mathrm{C}_{0},(\%)$ & $\mathrm{C}_{\mathrm{CI},} \%$ & $\mathrm{D}_{\mathrm{CI}} \%$ & $\mathrm{C}_{0},(\%)$ & $\mathrm{C}_{\mathrm{CI},} \%$ & $\mathrm{D}_{\mathrm{CI},} \%$ \\
\hline 1 & 2 & 3 & 4 & 5 & 6 & 7 \\
\hline 15 & 1,81 & 1,56 & 13,64 & 1,81 & 1,66 & 8,02 \\
\hline 20 & 1,77 & 1,51 & 14,35 & 1,77 & 1,57 & 11,11 \\
\hline 25 & 1,73 & 1,47 & 15,06 & & & \\
\hline 30 & 1,81 & 1,29 & 28,54 & 1,81 & 1,35 & 25,58 \\
\hline
\end{tabular}

Uočeno je da na NGB barute, $u$ poređenju sa jednobaznim, pogotovo NC barutima, manje utiču nepovoljni uslovi skladištenja kakvi vladaju u zoni KB-2. To se može objasniti činjenicom da NGB baruti imaju povoljniji sastav od NC baruta (manji sadržaj NC u barutnoj masi, manji sadržaj azota $\mathrm{u}$ NC, manji početni sadržaj vlage i manju higroskopnost). Takođe, nitroglicerin vrši impregnaciju i želatinizaciju molekula nitroceluloze i čini ih stabilnijim.

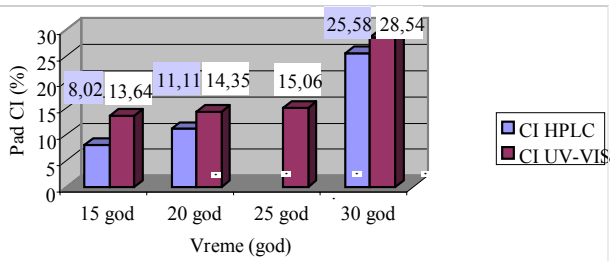

Sl. 9 - Zavisnost pada stabilizatora NGB baruta iz KB-2 sa vremenom

\section{NGH baruti}

Sumarni prosečni rezultati ispitivanja promene sadržaja stabilizatora dve vrste NGH baruta iz KB-1 i KB-2 prikazani su u tabeli 7. Slično opisanim barutima, i dvobazni NGH baruti iz KB-2 pokazuju manju stabilnost.

I kod NGH baruta određene serije, različitih godina proizvodnje, iste vrste baruta nakon jednakog perioda skladištenja $u$ istoj kolekciji pokazuju različitu stabilnost, što se, kao u prethodnim slučajevima, može objasniti razlikama u tehnološkom postupku ili u kvalitetu sirovina (tabela 7).

Tabela 7

Rezultati ispitivanja sadržaja stabilizatora NGH baruta različitih godina starosti

\begin{tabular}{|c|c|c|c|c|c|c|c|c|c|c|c|c|}
\hline \multirow[b]{2}{*}{$\begin{array}{l}\dot{\vec{b}} \\
\dot{0} \\
\text { ये }\end{array}$} & \multirow[b]{2}{*}{$\begin{array}{c}\text { Vrsta } \\
\text { baruta }\end{array}$} & \multirow[b]{2}{*}{ 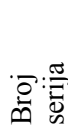 } & \multirow[b]{2}{*}{$t_{\mathrm{sk}}$} & \multirow[b]{2}{*}{$\begin{array}{c}\mathrm{C}_{0} \\
(\%)\end{array}$} & \multicolumn{2}{|c|}{$\mathrm{C}_{\mathrm{CI}}, \%$} & \multicolumn{2}{|c|}{$\mathrm{D}_{\mathrm{CI}}, \%$} & \multirow[b]{2}{*}{$\mathrm{SD}_{\mathrm{CI}}$} & \multirow[b]{2}{*}{$\delta_{\mathrm{CI}}$} & \multirow[b]{2}{*}{$\tau$} & \multirow[b]{2}{*}{ 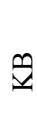 } \\
\hline & & & & & UV-VIS & HPLC & $\begin{array}{l}\text { UV- } \\
\text { VIS }\end{array}$ & HPLC & & & & \\
\hline 1 & 2 & 3 & 4 & 5 & 6 & 7 & 8 & 9 & 10 & 11 & 12 & 13 \\
\hline 1. & NGH-B & 9 & 15 & 3,07 & 2,92 & & 4,83 & & 0,04 & 0,03 & 230,5 & \\
\hline 2. & NGH-A & 17 & 30 & 3,21 & 2,86 & & 10,90 & & 0,14 & 0,09 & 201,4 & 1 \\
\hline 3. & AV & 13,0 & 22,50 & 3,14 & 2,89 & & 7,87 & & 0,04 & $\mathbf{0 , 0 3}$ & 216,0 & \\
\hline 4. & NGH-A & 5 & 15 & 3,18 & 2,77 & & 12,94 & & 0,11 & 0,07 & 171,5 & \\
\hline 5. & NGH-B & 15 & 20 & 3,12 & 2,81 & & 9,92 & & 0,11 & 0,07 & 156,8 & $?$ \\
\hline 6. & NGH-A & 3 & 25 & 3,16 & 2,76 & & 12,69 & & 0,14 & 0,09 & 134,8 & 2 \\
\hline 7. & AV & 7,7 & 20,0 & 3,15 & 2,78 & & 11,85 & & $\mathbf{0 , 0 3}$ & 0,02 & 154,4 & \\
\hline 8. & NGH-A & 5 & 15 & 3,18 & & 2,82 & & 11,53 & 0,10 & 0,07 & 180,7 & \\
\hline 9. & NGH-B & 15 & 20 & 3,12 & & 2,89 & & 7,29 & 0,05 & 0,04 & 188,2 & 2 \\
\hline 10. & NGH-A & 3 & 25 & 3,16 & & 2,79 & & 11,61 & 0,04 & 0,02 & 142,2 & 2 \\
\hline 11. & AV & 7,7 & 20,0 & 3,15 & & 2,83 & & 10,14 & 0,05 & $\mathbf{0 , 0 3}$ & 170,4 & \\
\hline 12. & NGH-A & 4 & 25 & 3,14 & 3,04 & & 3,19 & & 0,03 & 0,02 & 541,1 & \\
\hline 13. & NGH-A & 3 & 25 & 3,16 & 2,76 & & 12,69 & & 0,14 & 0,09 & 134,8 & 2 \\
\hline 14. & NGH-A & 4 & 25 & 3,14 & & 3,05 & & 3,03 & 0,05 & 0,04 & 631,3 & 2 \\
\hline 15. & NGH-A & 3 & 25 & 3,16 & & 2,79 & & 11,61 & 0,04 & 0,02 & 142,2 & \\
\hline 16. & NGH-A & 4 & 35 & 3,08 & 2,85 & & 7,54 & & 0,09 & 0,06 & 331,2 & 1 \\
\hline
\end{tabular}


U poređenju sa NGB barutima, NGH baruti su stabilniji, i to u uslovima obe kolekcije, pogotovo u nepovoljnim uslovima smeštaja kakvi vladaju u zoni KB-2. To je uslovljeno optimalnim hemijskim sastavom (DNT, DBF, DEF i manji saržaj NGL) i povoljnim oblikom barutnog zrna (jednokanalna cevčica) NGH baruta. Na slici 10 prikazani su uporedni rezultati stabilnosti.

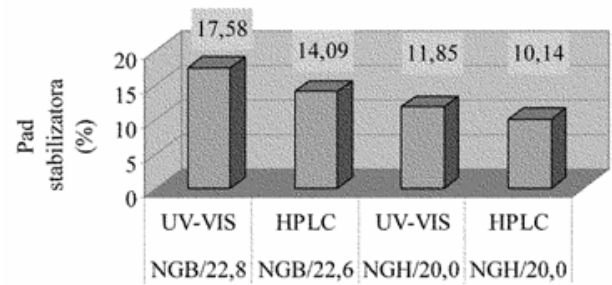

Sl. 10 - Poređenje pada stabilizatora za NGB $i$ NGH barute

U poređenju sa jednobaznim barutima, dvobazni baruti pokazuju bolju stabilnost (slike 11 i 12), što se objašnjava činjenicom da dvobazni baruti imaju povoljniji sastav (naročito NGH baruti), manju poroznost, homogeniju strukturu, veći stepen želatinizacije nitroceluloze, manji početni sadržaj vlage i manju higroskopnost, što u krajnjem rezultira boljom hemijskom stabilnošću.

Međutim, pitanje je pouzdanosti dobijenih rezultata za dvobazne barute, jer su na osnovu analize rezultata uočene sledeće pojave:

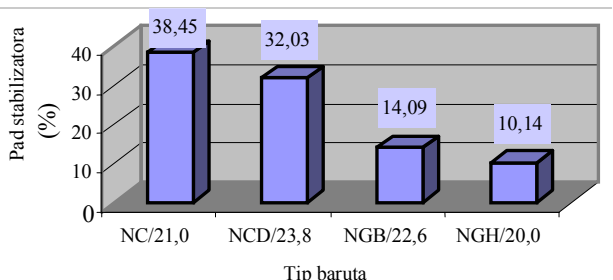

Sl. 11 - Poređenje pada stabilizatora jednobaznih $i$ dvobaznih baruta iz $K B-2$

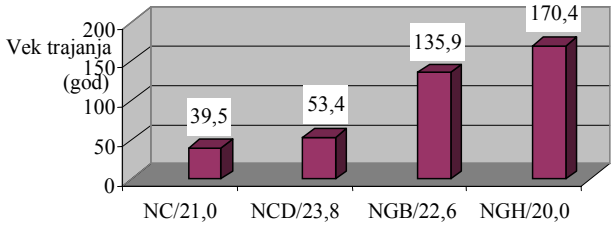

Sl. 12 - Poređenje veka trajanja jednobaznih $i$ dvobaznih baruta iz $K B-2$

- često se dešava da se nakon perioda skladištenja od 15 i više godina dobiju veće vrednosti preostalog sadržaja stabilizatora od vrednosti početnog (određen analitičkim merenjem), što je očigledna eksperimentalna greška. To je uočeno kod svih baruta koji u svom sastavu imaju CI, bilo u svojstvu stabilizatora (dvobazni baruti) ili u svojstvu modifikatora (pojedini jednobazni baruti npr. NC-C);

- uočena je zavisnost rezultata ispitivanja sadržaja stabilizatora CI od metode. Naime, po UV-VIS metodi dobijaju se manje vrednosti sadržaja CI, veći pad stabilizatora i kraći vek trajanja dvobaznih baruta nego po HPLC metodi.

\section{Zaključak}

Hemijska stabilnost baruta zavisi od mnogo faktora, pre svega od uslova skladištenja. Svi analizirani baruti pokazuju manju stabilnost u nepovoljnijim uslovima čuvanja, kakvi vladaju u KB-2, naročito NC baruti kod kojih se nakon 15 do 20 godina provedenih u KB-2 naglo ubrzava proces degradacije, a mehanizam reakcije utroška stabilizatora menja od prvog ka nultom. Pored toga, hemijska stabilnost zavisi od sastava - jednobazni baruti su manje stabilni od dvobaznih. U okviru jednobaznih baruta, NCD baruti su stabilniji od NC baruta, jer sadrže DNT, koji vrši želatinizaciju molekula 
NC i čini ih znatno stabilnijim. Takođe, NGH baruti su stabilniji od NGB baruta zbog povoljnijeg sastava.

Uočeno je da hemijska stabilnost baruta zavisi i od dimenzija i oblika barutnog zrna. Sa tog aspekta može se zaključiti da jednokanalna cevčica ima povoljan oblik, jer omogućava bržu izmenu nastale toplote sa okolinom, čime se usporava autokataliza degradacije baruta. Kod dvobaznih baruta uočena je zavisnost rezultata sadržaja CI od metode po UV-VIS metodi se dobijaju manje vrednosti sadržaja CI, veći pad stabilizatora i samim tim kraći vek trajanja baruta $\mathrm{u}$ odnosu na HPLC metodu. Ovaj fenomen do sada nije analiziran. Potrebno je utvrditi uzroke postojanja razlika $\mathrm{i}, \mathrm{u}$ skladu s tim, predložiti korekciju SNO za ispitivanje hemijske stabilnosti baruta.

Literatura:

[1] Maksimović P., V.: Eksplozivne materije, VIZ, Beograd 1985.

[2] Praćenje hemijske stabilnosti baruta i raketnih goriva SNO 8069/91, Beograd 1991.

[3] Comprehensive Summaries of Uppsala Dissertations from the Faculty of Science and Technology 935 ,Reactions in the System Nitro-cellulose/ Diphenylamine with Special Reference to the Formacion of a Stabiliying Product Bonded to Nitro-cellulose“, BY TORBJORN LINDBLON, ACTA UNIVERSITATIS UPSALIENSIS, Uppsala, 2004.

[4] Grbović, L: Hemijska degradacija baruta, Magistarski rad, Tehnološki fakultet, Zagreb, 1985.

[5] SNO broj: 7118/94 (NC-18), 1243/89 (NC-27), 1240/94 (NC-29), 1261/89 (NC-37), 1175/84 (NC-38), 1189/84 (NC-40), 7653/97 (NC-70), 7883/88 (NC-123), 1194/89 (NCD-11), 1195/89 (NCD-21), 1218/95 (NCD-27), 1269/84 (NGB-061), 1178/84 (NGB-081), 1167/94 (NGB161), 1179/84 (NGB-231), 1224/94 (NBG-261), 1170/84 (NGH-215) i 1268/92 (NGH-285).

[6] Zbornik radova Kvalitet uskladištenih UbS, Tematski skup TU GŠVJ, Beograd 1994. 
Tabela 1

Sastav ispitivanih baruta

\begin{tabular}{|c|c|c|c|c|c|c|c|}
\hline $\begin{array}{c}\text { Tip i } \\
\text { vrsta } \\
\text { baruta }\end{array}$ & $\begin{array}{c}\% \\
\mathrm{NC}\end{array}$ & $\begin{array}{c}\% \mathrm{~N}_{2} \mathrm{u} \\
\mathrm{NC}\end{array}$ & $\begin{array}{c}\% \\
\text { NGL }\end{array}$ & $\begin{array}{c}\% \\
\text { DNT }\end{array}$ & $\begin{array}{c}\% \\
\text { DFA }\end{array}$ & $\begin{array}{c}\% \\
\text { CI }\end{array}$ & $\begin{array}{c}\% \\
\text { vlage }\end{array}$ \\
\hline 1 & 2 & 3 & 4 & 5 & 6 & 7 & 8 \\
\hline NC-A & 97,5 & 13,10 & & & 1,60 & & 1,30 \\
\hline NC-B & 96,8 & 13,10 & & & 1,50 & & 1,35 \\
\hline NC-C & 94,3 & 13,05 & & & 1,20 & 4,00 & 1,25 \\
\hline NC-D & 96,7 & 13,10 & & & 1,50 & & 1,35 \\
\hline NC-E & 97,4 & 13,10 & & & 1,60 & & 1,30 \\
\hline NC-F & 97,5 & 12,95 & & & 1,10 & & 1,30 \\
\hline NC-G & 96,8 & 13,25 & & & 1,40 & & 1,20 \\
\hline NC-H & 96,75 & 13,00 & & & 1,50 & & 1,35 \\
\hline NCD-A & 82,9 & 13,05 & & 9,75 & 1,30 & & 0,60 \\
\hline NCD-B & 82,6 & 13,05 & & 9,75 & 1,30 & & 0,60 \\
\hline NCD-C & 86,0 & 13,05 & & 9,75 & 1,30 & & 0,60 \\
\hline NGB-A & 57,5 & 12,75 & 40,50 & & & 1,70 & 0,50 \\
\hline NGB-B & 57,5 & 12,75 & 40,50 & & & 1,70 & 0,50 \\
\hline NGB-C & 58,0 & 12,15 & 40,00 & & & 1,70 & 0,30 \\
\hline NGB-D & 57,5 & 12,75 & 40,50 & & & 1,70 & 0,30 \\
\hline NGB-E & 58,0 & 12,15 & 40,00 & & & 1,70 & 0,30 \\
\hline NGH-A & 56,0 & 12,05 & 26,80 & 9,00 & & 3,00 & 0,70 \\
\hline NGH-B & 56,0 & 12,05 & 26,60 & 9,00 & & 3,00 & 0,70 \\
\hline
\end{tabular}

Tabela 2

Rezultati ispitivanja sadržaja stabilizatora NC baruta

\begin{tabular}{|c|c|c|c|c|c|c|c|c|c|c|c|c|c|c|c|c|}
\hline \multirow[b]{2}{*}{$\begin{array}{l}\dot{\vec{b}} \\
\dot{\vec{d}} \\
\widetilde{\Delta}\end{array}$} & \multirow[b]{2}{*}{ 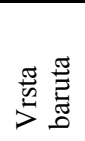 } & \multirow[b]{2}{*}{ 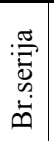 } & \multirow[b]{2}{*}{$\mathrm{t}_{\mathrm{sk}}$} & \multirow[b]{2}{*}{$\begin{array}{c}\mathrm{C}_{0} \\
(\%)\end{array}$} & \multicolumn{4}{|c|}{ C, $\%$ (HPLC) } & \multirow[b]{2}{*}{ 荕 } & \multirow[b]{2}{*}{ 离 } & \multicolumn{2}{|c|}{ SD } & \multicolumn{2}{|c|}{$\delta$} & \multirow[b]{2}{*}{$\tau$} & \multirow[b]{2}{*}{$\underline{v}$} \\
\hline & & & & & DFA & $\begin{array}{l}\text { NNO- } \\
\text { DFA }\end{array}$ & $\begin{array}{l}2 \mathrm{~N}- \\
\text { DFA }\end{array}$ & $\begin{array}{l}\text { 4N- } \\
\text { DFA }\end{array}$ & & & 㭊 & $\sum_{4}^{0}$ & 崩 & $\begin{array}{l}\frac{0}{4} \\
\frac{1}{0}\end{array}$ & & \\
\hline 1 & 2 & 3 & 4 & 5 & 6 & 7 & 8 & 9 & 10 & 11 & 12 & 13 & 14 & 15 & 16 & 17 \\
\hline 1. & NC-B & 6 & 25 & 1,48 & 1,16 & 0,09 & 0,03 & 0,04 & 21,54 & 10,68 & 0,02 & 0,09 & 0,01 & 0,06 & 72,2 & 1 \\
\hline 2. & NC-D & 9 & 25 & 1,46 & 1,17 & 0,10 & 0,02 & 0,03 & 19,73 & 9,30 & 0,05 & 0,10 & 0,03 & 0,07 & 80,2 & 1 \\
\hline 3. & NC-A & 9 & 30 & 1,59 & 1,32 & 0,15 & 0,06 & 0,04 & 17,24 & 1,54 & 0,04 & 0,04 & 0,03 & 0,03 & 111,7 & 1 \\
\hline 4. & NC-E & 14 & 30 & 1,61 & 1,21 & 0,16 & 0,03 & 0,03 & 25,01 & 10,85 & 0,08 & 0,15 & 0,05 & 0,10 & 76,2 & 1 \\
\hline 5. & AV & 9,5 & 27,5 & 1,54 & 1,22 & 0,13 & \begin{tabular}{|l|l|}
0,04 \\
\end{tabular} & \begin{tabular}{|l|l|}
0,04 \\
\end{tabular} & 20,88 & 8,09 & $\mathbf{0 , 0 7}$ & 0,12 & 0,05 & $0,0,08$ & 85,1 & 1 \\
\hline 6. & NC-D & 9 & 15 & 1,62 & 0,77 & 0,29 & 0,10 & 0,15 & 52,72 & 19,21 & 0,33 & 0,12 & 0,21 & 0,08 & 18,8 & 2 \\
\hline 7. & NC-F & 6 & 15 & 1,43 & 1,15 & 0,16 & 0,03 & 0,04 & 19,39 & 3,43 & 0,08 & 0,07 & 0,05 & 0,05 & 57,3 & 2 \\
\hline 8. & $\mathrm{NC}-\mathrm{H}$ & 10 & 15 & 1,55 & 1,28 & 0,15 & 0,04 & 0,02 & 17,29 & 3,72 & 0,05 & 0,05 & 0,03 & 0,03 & 57,0 & 2 \\
\hline 9. & NC-A & 9 & 30 & 1,59 & 0,95 & 0,18 & 0,07 & 0,00 & 40,48 & 24,97 & 0,05 & 0,05 & 0,03 & 0,03 & 40,4 & 2 \\
\hline 10. & NC-E & 13 & 30 & 1,61 & 0,60 & 0,24 & 0,08 & 0,07 & 62,35 & 37,96 & 0,29 & 0,15 & 0,19 & 0,09 & 24,0 & 2 \\
\hline 11. & AV & 9,4 & 21,0 & 1,56 & 0,95 & $\mathbf{0 , 2 0}$ & 0,06 & 0,06 & 38,45 & 17,86 & 0,28 & 0,19 & 0,18 & 0,12 & 39,5 & 2 \\
\hline 12. & & 9 & & & 1,32 & 0,15 & 0,06 & 0,04 & 17,24 & 1,54 & 0,04 & 0,04 & 0,03 & 0,03 & 111,7 & 1 \\
\hline 13. & & 7 & 3 & & 0,95 & 0,18 & 0,07 & 0,00 & 40,48 & 24,97 & 0,05 & 0,05 & 0,03 & 0,03 & 40,4 & 2 \\
\hline 14. & & 6 & 30 & & 1,28 & 0,18 & 0,06 & 0,05 & 20,16 & 1,99 & 0,02 & 0,03 & 0,02 & 0,02 & 93,2 & 1 \\
\hline 15. & & 0 & & & 0,82 & 0,19 & 0,06 & 0,02 & 48,43 & 31,85 & 0,15 & 0,09 & 0,10 & 0,06 & 32,6 & 2 \\
\hline
\end{tabular}

NAPOMENA: $\mathrm{D}_{\mathrm{DFA}}=\left(\mathrm{C}_{0}-\mathrm{C}\right) \times 100 / \mathrm{C}_{0}, \mathrm{D}_{\mathrm{DFAef}}=\left(\mathrm{C}_{0}-\mathrm{C}_{\mathrm{ef}}\right) \times 100 / \mathrm{C}_{0}, \mathrm{SD}=$ standardna devijacija, $\delta=$ ostupanje od srdnje vrednosti, $\mathrm{AV}=$ srednja vrednost. 
Tabela 3

Rezultati ispitivanja sadržaja stabilizatora NC baruta iz KB-2 karakteristični primeri

\begin{tabular}{|c|c|c|c|c|c|c|c|c|c|c|c|c|c|c|c|c|}
\hline \multirow[b]{2}{*}{$\begin{array}{l}\dot{\overrightarrow{0}} \\
\dot{\vec{d}} \\
\ddot{2}\end{array}$} & \multirow[b]{2}{*}{ 葋 } & \multirow[b]{2}{*}{ 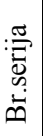 } & \multirow[b]{2}{*}{$\mathrm{t}_{\mathrm{sk}}$} & \multirow[b]{2}{*}{$\begin{array}{c}\mathrm{C}_{0} \\
(\%)\end{array}$} & \multicolumn{4}{|c|}{ C, \% (HPLC) } & \multirow[b]{2}{*}{ 吂 } & \multirow[b]{2}{*}{ 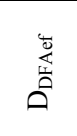 } & \multicolumn{2}{|c|}{ SD } & \multicolumn{2}{|c|}{$\delta$} & \multirow[b]{2}{*}{$\tau$} & \multirow[b]{2}{*}{$\underline{v}$} \\
\hline & & & & & DFA & $\begin{array}{l}\text { NNO- } \\
\text { DFA }\end{array}$ & $\begin{array}{l}2 \mathrm{~N}- \\
\text { DFA }\end{array}$ & $\begin{array}{l}\text { 4N- } \\
\text { DFA }\end{array}$ & & & 㭊 & $\sum_{\substack{4 \\
0}}^{0}$ & 㭊 & 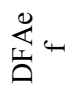 & & \\
\hline 1 & 2 & 3 & 4 & 5 & 6 & 7 & 8 & 9 & 10 & 11 & 12 & 13 & 14 & 15 & 16 & 17 \\
\hline 1. & \multirow{5}{*}{ NC-A } & 9 & 30 & \multirow{5}{*}{1,59} & 0,95 & 0,18 & 0,07 & 0,00 & 40,48 & 24,97 & 0,05 & 0,05 & 0,03 & 0,03 & 40,35 & 2 \\
\hline 2. & & 5 & 30 & & 0,52 & 0,28 & 0,08 & 0,10 & 67,14 & 37,51 & 0,16 & 0,13 & 0,10 & 0,08 & 19,25 & 2 \\
\hline 3. & & \multirow{3}{*}{3} & 30 & & 0,15 & 0,33 & 0,14 & 0,13 & 90,30 & 52,76 & 0,04 & 0,06 & 0,02 & 0,04 & 8,90 & \multirow{3}{*}{2} \\
\hline 4. & & & 31 & & 0,13 & 0,30 & 0,14 & 0,16 & 92,01 & 54,37 & 0,05 & \begin{tabular}{|l|}
0,07 \\
\end{tabular} & 0,03 & 0,04 & & \\
\hline 5. & & & 32 & & 0,02 & 0,36 & 0,16 & 0,21 & 98,72 & 52,57 & 0,03 & 0,07 & 0,02 & 0,04 & & \\
\hline 6. & \multirow{4}{*}{ NC-B } & \multirow{2}{*}{3} & \multirow{2}{*}{$15-16$} & \multirow{2}{*}{1,54} & 1,17 & 0,12 & 0,04 & 0,04 & 24,41 & 11,03 & 0,06 & 0,09 & 0,04 & 0,06 & 40,32 & 1 \\
\hline 7. & & & & & 0,02 & 0,36 & 0,13 & 0,13 & 98,49 & 57,50 & 0,02 & 0,15 & 0,01 & 0,10 & 2,93 & 2 \\
\hline 8. & & \multirow{2}{*}{1} & 15 & \multirow{2}{*}{1,64} & 1,24 & 0,16 & 0,04 & 0,08 & 24,39 & 7,32 & & & & & 39,67 & 2 \\
\hline 9. & & & 18 & & 0,00 & 0,03 & 0,11 & 0,06 & 100,0 & 87,80 & & & & & - & 2 \\
\hline 10. & \multirow{2}{*}{ NC-D } & \multirow{2}{*}{3} & \multirow{2}{*}{15} & \multirow{2}{*}{1,45} & 1,12 & 0,18 & 0,04 & 0,03 & 23,22 & 5,60 & 0,11 & 0,05 & 0,07 & 0,03 & 41,73 & 1 \\
\hline 11. & & & & & 0,36 & 0,30 & 0,10 & 0,12 & 76,22 & 40,14 & 0,34 & 0,47 & 0,22 & 0,31 & 10,37 & 2 \\
\hline 12. & \multirow{2}{*}{$\mathrm{NC}-\mathrm{F}$} & \multirow{2}{*}{4} & 15 & \multirow{2}{*}{1,41} & 1,20 & 0,16 & 0,03 & 0,03 & 14,85 & $-0,95$ & 0,03 & 0,04 & 0,02 & 0,02 & 70,42 & 2 \\
\hline 13. & & & 19 & & 0,00 & 0,17 & 0,17 & 0,19 & 100,0 & 62,41 & 0,00 & \begin{tabular}{|l|}
0,09 \\
\end{tabular} & - & 0,06 & - & 2 \\
\hline 14. & 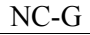 & 3 & 10 & 99 & 0,38 & 0,61 & 0,10 & 0,21 & 65,46 & 19,25 & 0,23 & 0,17 & 0,15 & 0,11 & 6,99 & 2 \\
\hline 15. & \multirow{4}{*}{ NC-H } & & 17 & & 0,36 & 0,31 & 0,13 & 0,17 & 77,98 & 43,16 & 0,09 & 0,05 & 0,06 & 0,03 & 7,82 & 2 \\
\hline 16. & & 4 & 18 & 164 & 0,21 & 0,40 & 0,12 & 0,17 & 87,30 & 45,31 & 0,09 & 0,07 & 0,06 & 0,05 & 5,70 & 2 \\
\hline 17. & & 4 & 19 & 1,04 & 0,18 & 0,34 & 0,13 & 0,13 & 89,01 & 52,53 & 0,02 & 0,04 & 0,01 & 0,03 & 5,33 & 2 \\
\hline 18. & & & 21 & & 0,09 & 0,43 & 0,13 & 0,17 & 94,53 & 50,26 & 0,03 & 0,05 & 0,02 & 0,04 & 4,04 & 2 \\
\hline
\end{tabular}




\begin{tabular}{|c|c|c|c|c|c|c|c|c|c|c|c|c|c|c|c|c|}
\hline \multirow[b]{2}{*}{$\begin{array}{l}\dot{\overrightarrow{0}} \\
\dot{\overrightarrow{0}} \\
\simeq\end{array}$} & \multirow[b]{2}{*}{ 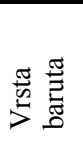 } & \multirow[b]{2}{*}{ 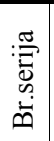 } & \multirow[b]{2}{*}{$t_{\mathrm{sk}}$} & \multirow[b]{2}{*}{$\begin{array}{c}\mathrm{C}_{0} \\
(\%)\end{array}$} & \multicolumn{4}{|c|}{ C, \% (HPLC) } & \multirow[b]{2}{*}{ 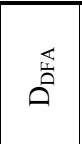 } & \multirow[b]{2}{*}{ 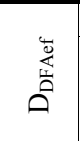 } & \multicolumn{2}{|c|}{ SD } & \multicolumn{2}{|c|}{$\delta$} & \multirow[b]{2}{*}{$\tau$} & \multirow[b]{2}{*}{$\underline{v}$} \\
\hline & & & & & DFA & $\begin{array}{l}\text { NNO- } \\
\text { DFA }\end{array}$ & $\begin{array}{c}2 \mathrm{~N}- \\
\mathrm{DFA}\end{array}$ & $\begin{array}{c}4 \mathrm{~N}- \\
\mathrm{DFA}\end{array}$ & & & 㭊 & $\sum_{\substack{4 \\
0}}^{0}$ & 㭊 & 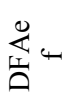 & & \\
\hline 1 & 2 & 3 & 4 & 5 & 6 & 7 & 8 & 9 & 10 & 11 & 12 & 13 & 14 & 15 & 16 & 17 \\
\hline 19. & NC-B & 4 & 15 & 1,60 & 0,11 & 0,29 & 0,18 & 0,29 & 93,47 & 45,87 & 0,11 & 0,57 & 0,07 & 0,37 & 3,71 & 2 \\
\hline 20. & NC-D & 6 & 20 & 1,60 & 0,13 & 0,41 & 0,15 & 0,20 & 91,76 & 43,98 & 0,04 & 0,06 & 0,03 & 0,04 & 5,53 & 2 \\
\hline 21. & NC-H & 7 & 19,3 & 1,60 & \begin{tabular}{|l|l|}
0,19 \\
\end{tabular} & 0,34 & 0,14 & 0,16 & 88,32 & 48,05 & 0,05 & 0,13 & 0,03 & 0,08 & \begin{tabular}{|l|l|}
6,19 \\
\end{tabular} & 2 \\
\hline 22. & NC-H & 7 & 21,3 & 1,60 & 0,08 & 0,41 & 0,14 & 0,17 & 94,86 & 50,06 & 0,04 & 0,04 & 0,02 & 0,03 & 4,89 & 2 \\
\hline 23. & AV & 6,0 & 19,0 & 1,60 & \begin{tabular}{l|l|}
0,13 \\
\end{tabular} & $\mathbf{0 , 3 6}$ & \begin{tabular}{|c|c|}
0,15 \\
\end{tabular} & \begin{tabular}{|l|l|}
0,21 \\
\end{tabular} & 92,10 & \begin{tabular}{|l|}
46,90 \\
\end{tabular} & $\mathbf{0 , 0 5}$ & \begin{tabular}{|l|}
0,04 \\
\end{tabular} & $\mathbf{0 , 0 3}$ & $\mathbf{0 , 0 3}$ & \begin{tabular}{|l|}
5,08 \\
\end{tabular} & 2 \\
\hline 24. & & 12 & 15 & 1,24 & 0,95 & 0,14 & 0,01 & 0,02 & 22,99 & \begin{tabular}{|l|}
9,84 \\
\end{tabular} & 0,14 & 0,12 & 0,09 & 0,08 & 48,78 & 2 \\
\hline 25. & & 6 & 20 & 1,20 & 0,05 & 0,34 & 0,09 & 0,16 & 96,23 & 46,85 & 0,07 & 0,16 & 0,04 & 0,11 & 4,69 & 2 \\
\hline 26. & NC-C & 5 & 15 & 4,36 & 3,59 & & & & 17,37 & & 0,24 & & 0,16 & & & 2 \\
\hline 27. & & 5 & 20 & 3,50 & 2,88 & & & & 17,53 & & 0,18 & & 0,12 & & & 2 \\
\hline 28. & & 6 & 26 & 3,31 & 2,55 & & & & 22,53 & & 0,20 & & 0,13 & & & 2 \\
\hline
\end{tabular}

NAPOMENA: rezultati od uzoraka iz KB-1 su dati radi poređenja, * - podaci se odnose na CI

Rezultati ispitivanja sadržaja stabilizatora NCD baruta

\begin{tabular}{|c|c|c|c|c|c|c|c|c|c|c|c|c|c|c|c|c|}
\hline \multirow[b]{2}{*}{$\begin{array}{l}\vec{\Xi} \\
\dot{\vec{d}} \\
\text { ح }\end{array}$} & \multirow[b]{2}{*}{ 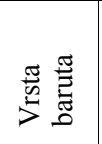 } & \multirow[b]{2}{*}{$\left|\begin{array}{c}: \frac{\pi}{\vec{Z}} \\
\stackrel{0}{0} \\
\stackrel{\mathscr{m}}{0}\end{array}\right|$} & \multirow[b]{2}{*}{$\mathrm{t}_{\mathrm{sk}}$} & \multirow[b]{2}{*}{$\begin{array}{c}\mathrm{C}_{0} \\
(\%)\end{array}$} & \multicolumn{4}{|c|}{$\mathrm{C}, \%$ (HPLC) } & \multirow[b]{2}{*}{ 崩 } & \multirow[b]{2}{*}{ 崖 } & \multicolumn{2}{|c|}{ SD } & \multicolumn{2}{|c|}{$\delta$} & \multirow[b]{2}{*}{$\tau$} & \multirow[b]{2}{*}{$\stackrel{n}{1}$} \\
\hline & & & & & DFA & $\begin{array}{l}\text { NNO- } \\
\text { DFA }\end{array}$ & $\begin{array}{l}\text { 2N- } \\
\text { DFA }\end{array}$ & $\begin{array}{l}\text { 4N- } \\
\text { DFA }\end{array}$ & & & 㭊 & $\sum_{\frac{1}{a}}^{0}$ & 㭊 & 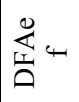 & & \\
\hline 1 & 2 & 3 & 4 & 5 & 6 & 7 & 8 & 9 & 10 & 11 & 12 & 13 & 14 & 15 & 16 & 17 \\
\hline 1. & NCD-A & 5 & 20 & 1,41 & 1,14 & 0,07 & 0,01 & 0,04 & 19,21 & 12,50 & 0,02 & 0,06 & 0,02 & 0,04 & 66,58 & 1 \\
\hline 2. & NCD-A & 5 & 26 & 1,42 & 1,14 & 0,12 & 0,02 & 0,00 & 19,32 & 9,15 & 0,04 & 0,04 & 0,03 & 0,03 & 89,01 & 1 \\
\hline 3. & NCD-B & 7 & 20 & 1,42 & 1,15 & 0,06 & 0,02 & 0,02 & 18,45 & 11,60 & 0,04 & 0,07 & 0,02 & 0,04 & 80,57 & 1 \\
\hline 4. & AV & 5,7 & 22,0 & 1,42 & 1,14 & 0,08 & 0,02 & 0,02 & 18,99 & 11,08 & \begin{tabular}{|l|}
0,01 \\
\end{tabular} & , 0,03 & $\mathbf{0 , 0 0}$ & 0,02 & 78,72 & 1 \\
\hline 5. & NCD-A & 7 & 25 & 1,40 & 1,03 & 0,09 & 0,08 & 0,03 & 25,89 & 11,57 & 0,05 & 0,06 & 0,03 & 0,04 & 59,66 & 2 \\
\hline 6. & NCD-B & 5 & 20 & 1,38 & 0,99 & 0,10 & 0,07 & 0,03 & 27,87 & 13,17 & 0,05 & 0,06 & 0,03 & 0,04 & 44,09 & 2 \\
\hline 7. & NCD-B & 8 & 25 & 1,44 & 0,77 & 0,17 & 0,12 & 0,05 & 46,19 & 22,92 & 0,25 & 0,15 & 0,16 & 0,10 & 33,85 & 2 \\
\hline 8. & NCD-C & 10 & 25 & 1,43 & 1,02 & 0,14 & 0,09 & 0,05 & 28,17 & 8,77 & 0,25 & 0,14 & 0,16 & 0,09 & 79,13 & 2 \\
\hline 9. & AV & 7,5 & 23,8 & 1,41 & 0,95 & 0,13 & 0,09 & 0,04 & 32,03 & 14,11 & 0,12 & $\mathbf{0 , 0 8}$ & $\mathbf{0 , 0 8}$ & 0,05 & 53,43 & 2 \\
\hline
\end{tabular}

Rezultati ispitivanja sadržaja stabilizatora NGB baruta

Tabela 5

\begin{tabular}{|l|l|l|l|l|l|l|l|l|l|l|}
\hline$\cdot$ & Vrsta & nq & $\mathrm{t}_{\mathrm{sk}}$ & $\mathrm{C}_{0}$ & $\mathrm{C}_{\mathrm{CI}, \%}$ & $\mathrm{D}_{\mathrm{CI}, \%}$ & $\mathrm{SD}_{\mathrm{CI}}$ & $\delta_{\mathrm{CI}}$ & $\tau$ & $\boldsymbol{}$ \\
\hline
\end{tabular}




\begin{tabular}{|c|c|c|c|c|c|c|c|c|c|c|c|c|}
\hline & & & & & UV-VIS & HPLC & $\begin{array}{l}\text { UV- } \\
\text { VIS }\end{array}$ & HPLC & & & & \\
\hline 1 & 2 & 3 & 4 & 5 & 6 & 7 & 8 & 9 & 10 & 11 & 12 & 13 \\
\hline 1. & \multirow{2}{*}{ NGB-B } & \multirow{2}{*}{4} & \multirow{2}{*}{25} & \multirow{2}{*}{1,78} & 1,58 & & 11,19 & & 0,14 & 0,09 & 186,6 & KB-1 \\
\hline 2. & & & & & 1,48 & & 16,67 & & 0,07 & 0,04 & 100,4 & KB-2 \\
\hline 3. & NGB-A & 8 & 22,8 & 1,77 & 1,46 & & 17,54 & & 0,09 & 0,06 & 86,0 & UbS \\
\hline 4. & \multirow{2}{*}{ NGB-B } & 4 & 25 & 1,78 & 1,48 & & 16,67 & & 0,07 & 0,04 & 100,4 & \multirow{10}{*}{ KB-2 } \\
\hline 5. & & 4 & 30 & 1,79 & 1,29 & & 27,82 & & 0,06 & 0,04 & 65,3 & \\
\hline 6. & \multirow{3}{*}{ NGB-C } & 3 & 15 & 1,84 & 1,56 & & 14,71 & & 0,12 & 0,08 & 80,7 & \\
\hline 7. & & 5 & 20 & 1,79 & 1,49 & & 16,44 & & 0,08 & 0,05 & 80,1 & \\
\hline 8. & & 4 & 25 & 1,70 & 1,46 & & 14,12 & & 0,08 & 0,05 & 120,9 & \\
\hline 9. & NGB-D & 4 & 30 & 1,82 & 1,29 & & 29,26 & & 0,06 & 0,04 & 60,9 & \\
\hline 10. & \multirow{3}{*}{ NGB-E } & 9 & 15 & 1,77 & 1,55 & & 12,57 & & 0,12 & 0,08 & 118,9 & \\
\hline 11. & & 14 & 20 & 1,74 & 1,52 & & 12,26 & & 0,09 & 0,06 & 119,5 & \\
\hline 12. & & 6 & 25 & 1,70 & 1,46 & & 14,40 & & 0,05 & 0,03 & 113,3 & \\
\hline 13. & AV & 6,1 & 22,8 & 1,77 & 1,46 & & $\mathbf{1 7 , 5 8}$ & & $\mathbf{0 , 0 9}$ & 0,06 & 91,7 & \\
\hline 14. & NGB-A & 8 & 22,8 & 1,77 & & 1,45 & & 18,54 & 0,08 & 0,06 & 80,1 & UbS \\
\hline 15. & NGB-B & 3 & 30 & 1,80 & & 1,34 & & 25,88 & 0,05 & 0,03 & 69,9 & \multirow{9}{*}{ KB-2 } \\
\hline 16. & \multirow{3}{*}{ NGB-C } & 3 & 15 & 1,84 & & 1,67 & & 8,96 & 0,07 & 0,05 & 154,3 & \\
\hline 17. & & 5 & 20 & 1,79 & & 1,60 & & 10,59 & 0,07 & 0,04 & 130,3 & \\
\hline 18. & & 3 & 25 & 1,72 & & 1,56 & & 9,68 & 0,08 & 0,05 & 179,2 & \\
\hline 19. & NGB-D & 4 & 30 & 1,82 & & 1,36 & & 25,27 & 0,02 & 0,02 & 71,7 & \\
\hline 20. & \multirow{3}{*}{ NGB-E } & 9 & 15 & 1,77 & & 1,64 & & 7,07 & 0,07 & 0,04 & 221,6 & \\
\hline 21. & & 14 & 20 & 1,74 & & 1,53 & & 11,62 & 0,06 & 0,04 & 125,3 & \\
\hline 22. & & 6 & 25 & 1,70 & & 1,55 & & 9,20 & 0,06 & 0,04 & 191,2 & \\
\hline 23. & AV & 6,1 & 22,5 & 1,77 & & 1,52 & & 14,09 & 0,12 & 0,08 & 135,9 & \\
\hline
\end{tabular}

Zbirni rezultati ispitivanja sadržaja stabilizatora NGB baruta,

Tabela 6 grupisani po godinama starosti

\begin{tabular}{|c|c|c|c|c|c|c|}
\hline \multirow{2}{*}{$t_{\mathrm{E}}$} & \multicolumn{3}{|c|}{ UV-VIS } & \multicolumn{3}{c|}{ HPLC } \\
\cline { 2 - 7 } & $\mathrm{C}_{0,}(\%)$ & $\mathrm{C}_{\mathrm{Cl}, \%}$ & $\mathrm{D}_{\mathrm{CI}, \%}$ & $\mathrm{C}_{0},(\%)$ & $\mathrm{C}_{\mathrm{CI}, \%}$ & $\mathrm{D}_{\mathrm{Cl}, \%}$ \\
\hline 1 & 2 & 3 & 4 & 5 & 6 & 7 \\
\hline 15 & 1,81 & 1,56 & 13,64 & 1,81 & 1,66 & 8,02 \\
\hline 20 & 1,77 & 1,51 & 14,35 & 1,77 & 1,57 & 11,11 \\
\hline 25 & 1,73 & 1,47 & 15,06 & & & \\
\hline 30 & 1,81 & 1,29 & 28,54 & 1,81 & 1,35 & 25,58 \\
\hline
\end{tabular}

Tabela 7

Rezultati ispitivanja sadržaja stabilizatora NGH baruta različitih godina starosti

\begin{tabular}{|c|c|c|c|c|c|c|c|c|c|c|c|c|}
\hline \multirow[b]{2}{*}{$\begin{array}{l}\dot{0} \\
\dot{0} \\
\ddot{0}\end{array}$} & \multirow[b]{2}{*}{$\begin{array}{l}\text { Vrsta } \\
\text { baruta }\end{array}$} & \multirow[b]{2}{*}{ 'D: } & \multirow[b]{2}{*}{$\mathrm{t}_{\mathrm{sk}}$} & \multirow[b]{2}{*}{$\begin{array}{c}\mathrm{C}_{0} \\
(\%)\end{array}$} & \multicolumn{2}{|c|}{$\mathrm{C}_{\mathrm{CI}, \%}$} & \multicolumn{2}{|c|}{$\mathrm{D}_{\mathrm{CI}, \%}$} & \multirow[b]{2}{*}{$\mathrm{SD}_{\mathrm{CI}}$} & \multirow[b]{2}{*}{$\delta_{\mathrm{CI}}$} & \multirow[b]{2}{*}{$\tau$} & \multirow[b]{2}{*}{$\underline{v}$} \\
\hline & & & & & UV-VIS & HPLC & $\begin{array}{l}\text { UV- } \\
\text { VIS }\end{array}$ & HPLC & & & & \\
\hline 1 & 2 & 3 & 4 & 5 & 6 & 7 & 8 & 9 & 10 & 11 & 12 & 13 \\
\hline 1. & NGH-B & 9 & 15 & 3,07 & 2,92 & & 4,83 & & 0,04 & 0,03 & 230,5 & \\
\hline 2. & NGH-A & 17 & 30 & 3,21 & 2,86 & & 10,90 & & 0,14 & 0,09 & 201,4 & 1 \\
\hline 3. & $\mathbf{A V}$ & 13,0 & 22,50 & 3,14 & 2,89 & & 7,87 & & 0,04 & $\mathbf{0 , 0 3}$ & 216,0 & \\
\hline 4. & NGH-A & 5 & 15 & 3,18 & 2,77 & & 12,94 & & 0,11 & 0,07 & 171,5 & 2 \\
\hline
\end{tabular}




\begin{tabular}{|c|c|c|c|c|c|c|c|c|c|c|c|c|}
\hline \multirow[b]{2}{*}{$\begin{array}{l}\dot{0} \\
\dot{0} \\
\check{0}\end{array}$} & \multirow[b]{2}{*}{$\begin{array}{l}\text { Vrsta } \\
\text { baruta }\end{array}$} & \multirow[b]{2}{*}{ 悹: } & \multirow[b]{2}{*}{$t_{\mathrm{sk}}$} & \multirow[b]{2}{*}{$\begin{array}{c}\mathrm{C}_{0} \\
(\%)\end{array}$} & \multicolumn{2}{|c|}{$\mathrm{C}_{\mathrm{CI}, \%}$} & \multicolumn{2}{|c|}{$\mathrm{D}_{\mathrm{CI}, \%}$} & \multirow[b]{2}{*}{$\mathrm{SD}_{\mathrm{CI}}$} & \multirow[b]{2}{*}{$\delta_{\mathrm{CI}}$} & \multirow[b]{2}{*}{$\tau$} & \multirow[b]{2}{*}{$\underline{\nabla}$} \\
\hline & & & & & UV-VIS & HPLC & $\begin{array}{l}\text { UV- } \\
\text { VIS }\end{array}$ & HPLC & & & & \\
\hline 1 & 2 & 3 & 4 & 5 & 6 & 7 & 8 & 9 & 10 & 11 & 12 & 13 \\
\hline 5. & NGH-B & 15 & 20 & 3,12 & 2,81 & & 9,92 & & 0,11 & 0,07 & 156,8 & \\
\hline 6. & NGH-A & 3 & 25 & 3,16 & 2,76 & & 12,69 & & 0,14 & 0,09 & 134,8 & \\
\hline 7. & AV & 7,7 & 20,0 & 3,15 & 2,78 & & 11,85 & & 0,03 & 0,02 & 154,4 & \\
\hline 8. & NGH-A & 5 & 15 & 3,18 & & 2,82 & & 11,53 & 0,10 & 0,07 & 180,7 & \\
\hline 9. & NGH-B & 15 & 20 & 3,12 & & 2,89 & & 7,29 & 0,05 & 0,04 & 188,2 & $?$ \\
\hline \multirow[t]{2}{*}{10} & NGH-A & 3 & 25 & 3,16 & & 2,79 & & 11,61 & 0,04 & 0,02 & 142,2 & 2 \\
\hline & AV & 7,7 & 20,0 & 3,15 & & 2,83 & & 10,14 & $\mathbf{0 , 0 5}$ & $\mathbf{0 , 0 3}$ & 170,4 & \\
\hline 11. & NGH-A & 4 & 25 & 3,14 & 3,04 & & 3,19 & & 0,03 & 0,02 & 541,1 & \multirow{4}{*}{2} \\
\hline 12. & NGH-A & 3 & 25 & 3,16 & 2,76 & & 12,69 & & 0,14 & 0,09 & 134,8 & \\
\hline 13. & NGH-A & 4 & 25 & 3,14 & & 3,05 & & 3,03 & 0,05 & 0,04 & 631,3 & \\
\hline 14. & NGH-A & 3 & 25 & 3,16 & & 2,79 & & 11,61 & 0,04 & 0,02 & 142,2 & \\
\hline 15. & NGH-A & 4 & 35 & 3,08 & 2,85 & & 7,54 & & 0,09 & 0,06 & 331,2 & 1 \\
\hline
\end{tabular}

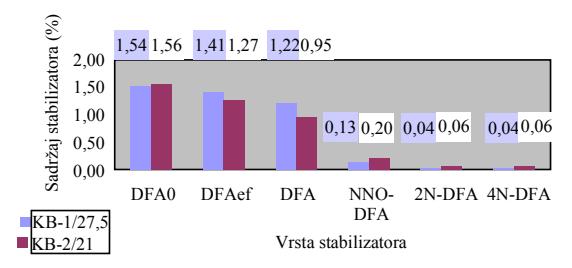

Sl. 1 - Prosečna promena sadržaja stabilizatora NC baruta nakon 27,5 godina u KB-1, odnosno 21 godinu $и \mathrm{~KB}-2$

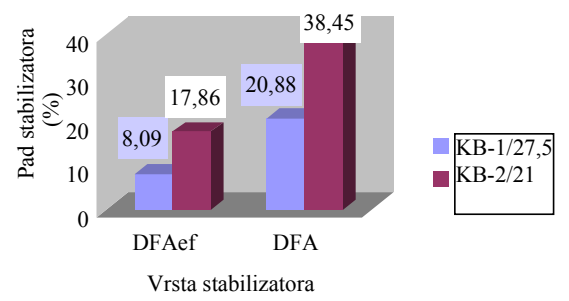

Sl. 2 - Pad sadržaja preostalog i efektivnog stabilizatora za NC barute nakon 27,5 godina u KB-1, odnosno 21 godinu u $\mathrm{KB}-2$ 


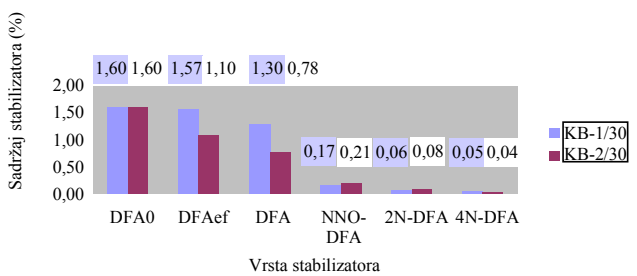

Sl. 3 - Zavisnost promene sadržaja stabilizatora baruta NC-A i NC-E od uslova čuvanja

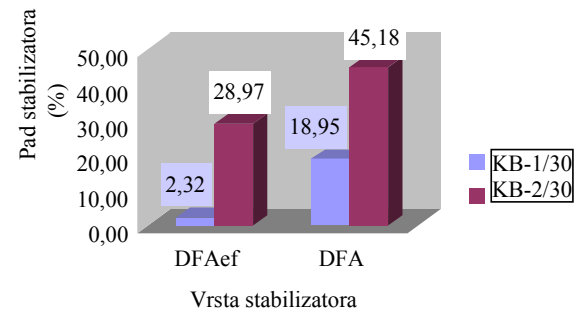

Sl. 4 - Zavisnost pada preostalog i efektivnog stabilizatora od uslova čuvanja za barute NC-A i NC-E

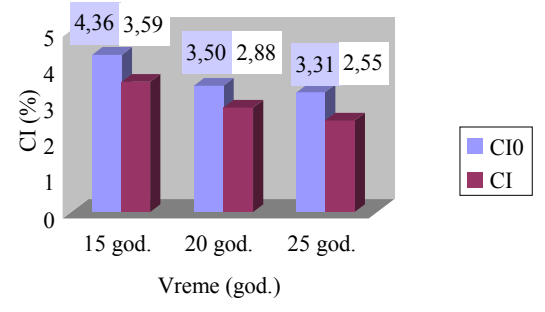

Sl. 5 - Utrošak CI sa vremenom u barutu NC-C 


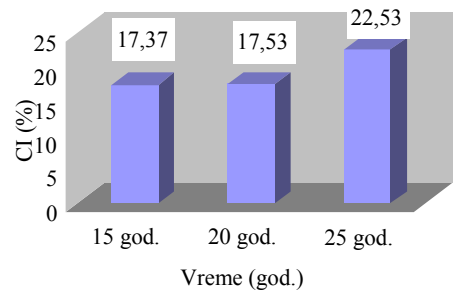

Sl. 6-Pad sadržaja CI sa vremenom u barutu NC-C

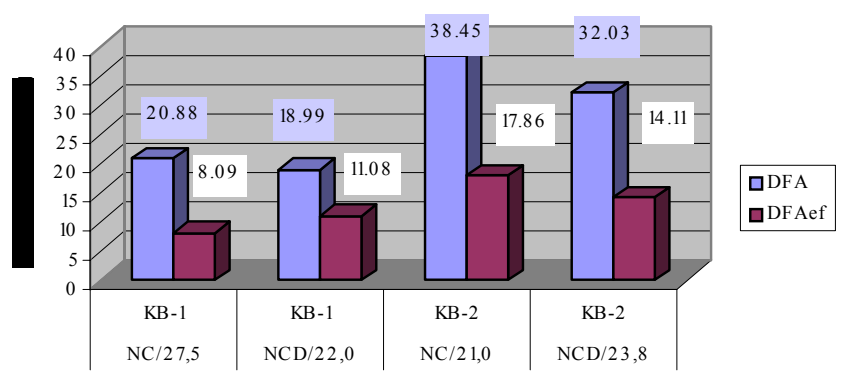

Sl. 7 - Poređenje pada stabilizatora za NC i NCD barute

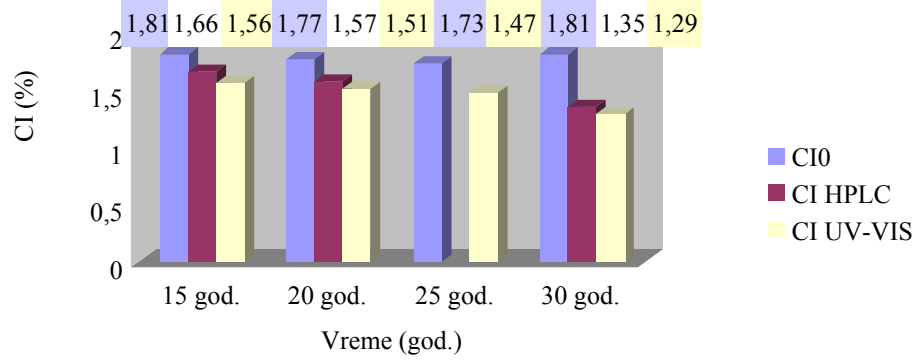




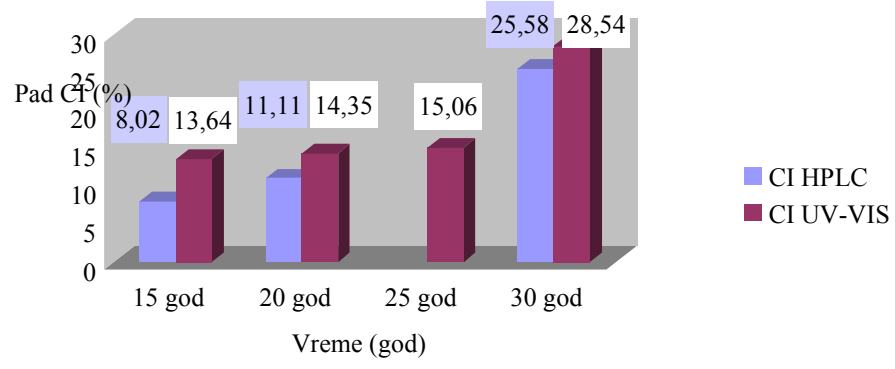

Sl. 9 -Zavisnost pada stabiizatora NGB baruta iz KB-2 sa vremenom

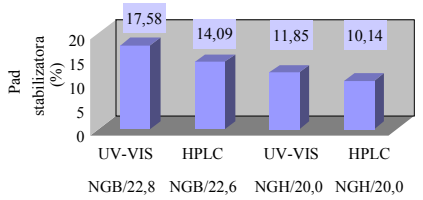

Sl. 10 - Poređenje pada stabilizatora za NGB i NGH barute

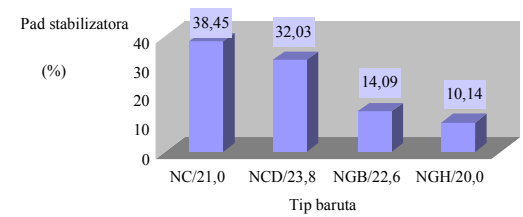

Sl. 11 - Poređenje pada stabilizatora jednobaznih i dvobaznih baruta iz KB-2

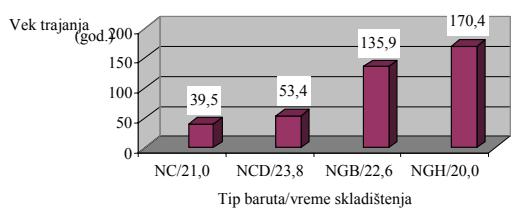

Sl. 12 - Poređenje veka trajanja jednobaznih i dvobaznih baruta iz KB-2 